\title{
Bisguanidine, Bis(2-aminoimidazoline) and Polyamine Derivatives as Potent and Selective Chemotherapeutic Agents against Trypanosoma brucei rhodesiense. Synthesis and in vitro evaluation.
}

\author{
Christophe Dardonville ${ }^{\mathrm{a}^{*}}$ and Reto Brun ${ }^{\mathrm{b}}$ \\ ${ }^{a}$ Instituto de Química Médica, CSIC, Juan de la Cierva, 3, 28006-Madrid, Spain \\ ${ }^{b}$ Swiss Tropical Institute, Socinstrasse 57, CH-4002 Basel, Switzerland
}

${ }^{*}$ Corrresponding author

Instituto de Química Médica, CSIC

Juan de la Cierva, 3, 28006-Madrid, Spain

Tel.: +34 91-562-2900

Fax.: +34 91-564-4853

E-mail : dardonville@iqm.csic.es 


\section{TOC Graphic}
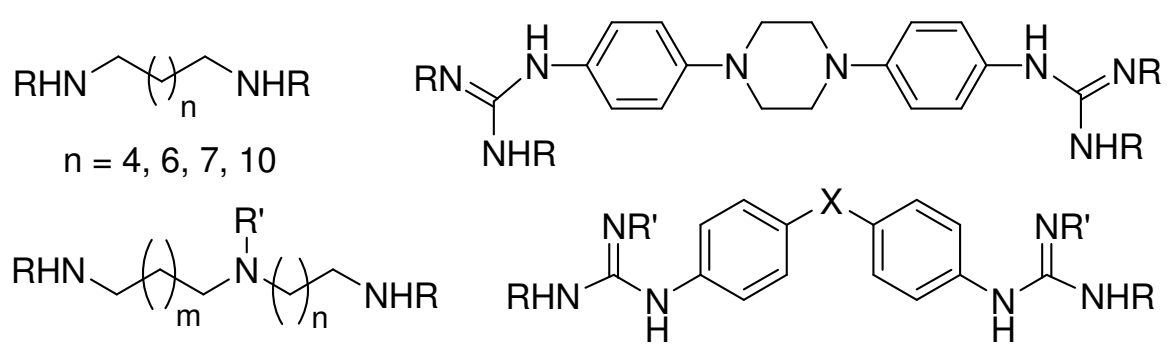

$$
\mathrm{m}=0,1 ; \mathrm{n}=1,2
$$

$\mathrm{X}=\mathrm{CH}_{2}, \mathrm{NH}, \mathrm{CO}, \mathrm{SO}_{2}$ 


\begin{abstract}
The in vitro screening for trypanocidal activity against T.b. rhodesiense of an inhouse library of 62 compounds [i.e. alkane, diphenyl and aza-alkane bisguanidines and bis(2-aminoimidazolines)] which were chosen for their structural similarity to the trypanocidal agents synthalin (1,10-decanediguanidine) and 4,4'diguanidinodiphenylmethane, and the polyamine $N^{l}$-(3-amino-propyl)-propane-1,3diamine respectively, is reported. The original synthetic procedure for the preparation of 21 of these compounds is also reported.

Most compounds displayed low micromolar anti-trypanosomal activity with five of them presenting a nanomolar inhibitory action on the parasite: 1,9-nonanediguanidine (1c), 1,12-dodecanediguanidine (1d), 4,4'-bis[1,3-di(tert-butoxycarbonyl)-2imidazolidinylimino]diphenylamine $\quad$ (28a), $\quad$ 4,4'-bis(4,5-dihydro- $1 H$-2imidazolylamino)diphenylamine (28b), 4,4'-diguanidinodiphenylamine (32b) and 1,4bis[4-(4,5-dihydro-1H-2-imidazolylamino)phenyl]piperazine (41b). Those molecules, which showed an excellent in vitro activity as well as high selectivity for the parasite [e.g. 1c $\left(\mathrm{IC}_{50}=49 \mathrm{nM} ; \mathrm{SI}>5294\right), \mathbf{2 8 b}\left(\mathrm{IC}_{50}=69 \mathrm{nM} ; \mathrm{SI}=3072\right), \mathbf{3 2 b}\left(\mathrm{IC}_{50}=22 \mathrm{nM}\right.$; $\left.\mathrm{SI}=29.5), \mathbf{4 1 b}\left(\mathrm{IC}_{50}=118 \mathrm{nM} ; \mathrm{SI}=881\right)\right]$, represent new anti-trypanosomal lead compounds.
\end{abstract}

Keywords: polyamine, guanidine, 2-aminoimidazoline, Trypanosoma brucei, antiprotozoal, chemotherapy 


\section{Introduction}

Sleeping sickness (Human African Trypanosomiasis, HAT) is caused by two subspecies of African trypanosomes, Trypanosoma brucei gambiense and T. brucei rhodesiense, responsible for the chronic and acute form of the disease respectively. ${ }^{1}$ Only four drugs are licensed for the treatment of $\mathrm{HAT}^{2}$ (DFMO, suramin, pentamidine and melarsoprol) although other drugs such as berenil (usually used against animal trypanosomiasis) or the nitrofuran nifurtimox (registered for use against Chagas' disease) have also proved useful in some limited cases. The actual situation of reemergence of sleeping sickness in sub-Saharan Africa, with prevalence of an estimated 500,000 infected individuals, ${ }^{3}$ and the drawbacks of the current HAT chemotherapy (e.g. toxicity, increasing resistance, parenteral mode of administration, price) make the search for new trypanocidal drugs urgently needed. ${ }^{4}$

Many diamidine, diguanidine and polyamine compounds have been investigated for their antitrypanosomal activity as far as 65 years ago, ${ }^{5-11}$ giving rise, for instance, to the aromatic diamidine drug pentamidine ${ }^{12}$ which is still used nowadays for the treatment of early stage T.b. gambiense infections. However, this drug is unable to cross the blood-brain barrier in sufficient quantity to treat late-stage cases of HAT. ${ }^{13}$ Other aromatic diamidines such as propamidine or berenil are used as antiprotozoal chemotherapy in cattle and the trypanocidal activity of dicationic derivatives related to pentamidine have been reported as well (Figure 1). ${ }^{9,14,15}$ The polyamine metabolic pathway of trypanosomatid parasites has attracted much attention as drug target for the last 15 years. ${ }^{16}$ This research led to the synthesis and evaluation of many polyamine analogues as chemotherapeutic agents against parasitic infections, ${ }^{17-20}$ being the trypanothione reductase a particularly targeted enzyme (Figure 1). ${ }^{21-23}$ 
There is a clear lack of research investment in the field of tropical diseases in comparison to the number of affected population. ${ }^{24,25}$ Thus, a reasonable approach for the discovery of new anti-trypanosomal lead compounds at a lesser cost is the screening for anti-parasitic activity of already available molecules. Hence, a rapid look at the structure of the polyamine, diguanidine and diamidine compounds reported as antiprotozoal agents in the literature put into evidence the potential as possible trypanocides of a series of bisguanidine and bis(2-aminoimidazoline) compounds previously synthesized in our laboratory for other purposes. ${ }^{26-28}$ Moreover, some of the alkanediguanidine $\left[1,8\right.$-octanediguanidine $(\mathbf{1 b}),{ }^{29}$ 1,12-dodecanediguanidine (1d) $), 3,30,31$ bis(guanidinopropyl)amine $\left.\quad(\mathbf{6 a})^{32}\right]$ and diphenyl compounds [4,4'diguanidinodiphenylmethane (31b), 4,4'-diguanidinodiphenylsulfone (33b) $]^{8}$ available in our in-house library had been previously reported for their use as either trypanocide, microbicides or fungicides. Of particular interest was the recent report on $N, N^{\prime}$-bis(4amidinophenyl)piperazine (Figure 1) which proved to be a very effective antitrypanosomal agent in vivo. ${ }^{15}$ Hence, in the search for new HAT chemotherapy, we decided to carry out an in vitro screening against the parasite T. brucei rhodesiense of a total of 62 compounds (Tables 1-5) taken from our in-house library and structurally related to the trypanocidal agents synthalin (1,10-decanediguanidine) and 4,4'diguanidinodiphenylmethane (31b), and the polyamine $N^{l}$-(3-amino-propyl)-propane1,3-diamine respectively. We also describe here the original synthesis of 21 molecules which had not been previously reported. 
<smiles>N=C(N)c1ccc(OCCOc2ccc(C(=N)N)cc2)cc1</smiles><smiles>N=C(N)c1ccc(N2CCN(c3ccc(C(=N)N)cc3)CC2)cc1</smiles>

$N, N$-bis(4-amidinophenyl)piperazine<smiles>[R]c1ccc(Cc2ccc([R])cc2)cc1</smiles><smiles>N=C(N)CCCCNC(=N)N</smiles>

(31b)<smiles>N=C(N)c1ccc(N=NNc2ccc(C(=N)N)cc2)cc1</smiles><smiles>N=C(N)c1cccc(/C=N/N=C(N)N/N=C/c2cccc(C(=N)N)c2)c1</smiles>

CGP 40215<smiles>N=C(N)CCCCCCCCCCCC(=N)N</smiles>

Undecanediamidine<smiles>N=C(N)NCCCCCCCCCCNC(=N)N</smiles><smiles>CCNCCCNCCCCCCCCNCCCNCC1CCCCCC1</smiles>

CHE-3-7-3

Figure 1

\section{Results}

\section{Chemistry}

Synthesis of the aliphatic compounds $1 \mathbf{a}-\mathbf{d}, \mathbf{2 a - d ,} \mathbf{3 b} \mathbf{b}-\mathbf{d}, \mathbf{4 a - b}, \mathbf{5 a}, \mathbf{5 b}, \mathbf{5 d}, \mathbf{6 a - b}, \mathbf{7}, \mathbf{8}$,

9, 11-13, 21-24 (Tables 1, 2, 3 and 4) as well as the diphenyl derivatives 27a-33a, 27b33b and 34 (Table 5, entry 1-15) has been previously reported by us. ${ }^{26,27,28}$

Synthesis of the 3-aza-1,6-hexanediamine derivatives (Scheme 1). Guanylation of 3-aza-1,6-hexanediamine with an excess of DCC in $\mathrm{CH}_{3} \mathrm{CN}$ afforded a mixture of the di-substituted dicyclohexylguanidine derivative $\mathbf{5 c}$ and the tri-substituted compound 17. These products were separated by preparative reverse phase HPLC. 
3-Aza-1,6-hexane diamine selectively protected on the primary amino group with benzylcyanoformate ${ }^{28,33}(\mathbf{5 d})$ was used as starting material for the preparation of the 3 substituted derivatives 8-10, 14-16, 18-20 and 25-26 (Scheme 1). Alkylation of 5d with bromoethylbenzene or 2-bromoethanol yielded 8 (83\%) and 20 (69\%) respectively. Hydrogenolysis of 8 with $10 \% \mathrm{Pd}-\mathrm{C} / 1 \mathrm{M} \mathrm{HCl} / \mathrm{MeOH}$ afforded the amine 9 which was subsequently refluxed with S-methylisothiouronium sulphate in $\mathrm{CH}_{3} \mathrm{CN}$, yielding the bis-guanidine 10 (46 \%). When $\mathbf{5 d}$ was treated with chloroacetaldehyde in excess under reductive conditions $\left(\mathrm{NaBH}(\mathrm{OAc})_{3} / \mathrm{AcOH} / \mathrm{CH}_{3} \mathrm{CN}\right)$ at room temperature, the chloroethyl derivative 19 (35\%) was obtained together with the acetate side-product 18 (16\%). In this reaction, the nucleophilic substitution of chloroacetaldehyde (or 2chloroethanol derived from the reduction in situ of chloroacetaldehyde) by the secondary amine $\mathbf{5 d}$, leading to a hydroxyethyl intermediate that can react with $\mathrm{AcOH}$ present in the reaction medium, is a potential competitive reaction. Working at low temperature $\left(0{ }^{\circ} \mathrm{C}\right)$ was unfavourable to the competitive nucleophilic substitution and $\mathbf{1 9}$ could be obtained in $69 \%$ in these conditions.

An interesting feature was the methylation of $\mathbf{5 d}$ with formaldehyde under reductive conditions $\left(\mathrm{NaBH}_{3} \mathrm{CN} / \mathrm{CH}_{3} \mathrm{CN}\right){ }^{34}$ Three main products were isolated depending on the $\mathrm{pH}$ of the reaction. Working in basic medium (i.e. $\mathrm{pH}>7$, no $\mathrm{AcOH}$ added) yielded the methylated product 14 (51\%) whereas acidic medium afforded both five and six-member ring aminals $\mathbf{2 5}$ and $\mathbf{2 6}$ respectively. Structural characterisation of both derivatives was carried out by $1 \mathrm{D}\left({ }^{1} \mathrm{H},{ }^{13} \mathrm{C}\right)$ and $2 \mathrm{D}-\mathrm{NMR}$ experiments (i.e. HSQC, HMBC). A characteristic difference between the ${ }^{1} \mathrm{H}$ NMR spectra of $\mathbf{2 5}$ and $\mathbf{2 6}$ were the aminal methylene protons which appeared as a singlet of two protons for the sixmember ring derivative $\mathbf{2 6}$ whereas two singlets (separated by $14.8 \mathrm{~Hz}$ ) were observed for the five member ring counterpart $\mathbf{2 5}$. This might account for the observation of two 
conformers of the acyl derivative $25 .{ }^{35}$ Study of the ${ }^{3} \mathrm{~J}_{\mathrm{H}-\mathrm{C}}$ coupling constants between the aminal methylene protons and their neighbours allowed to characterising both compounds.

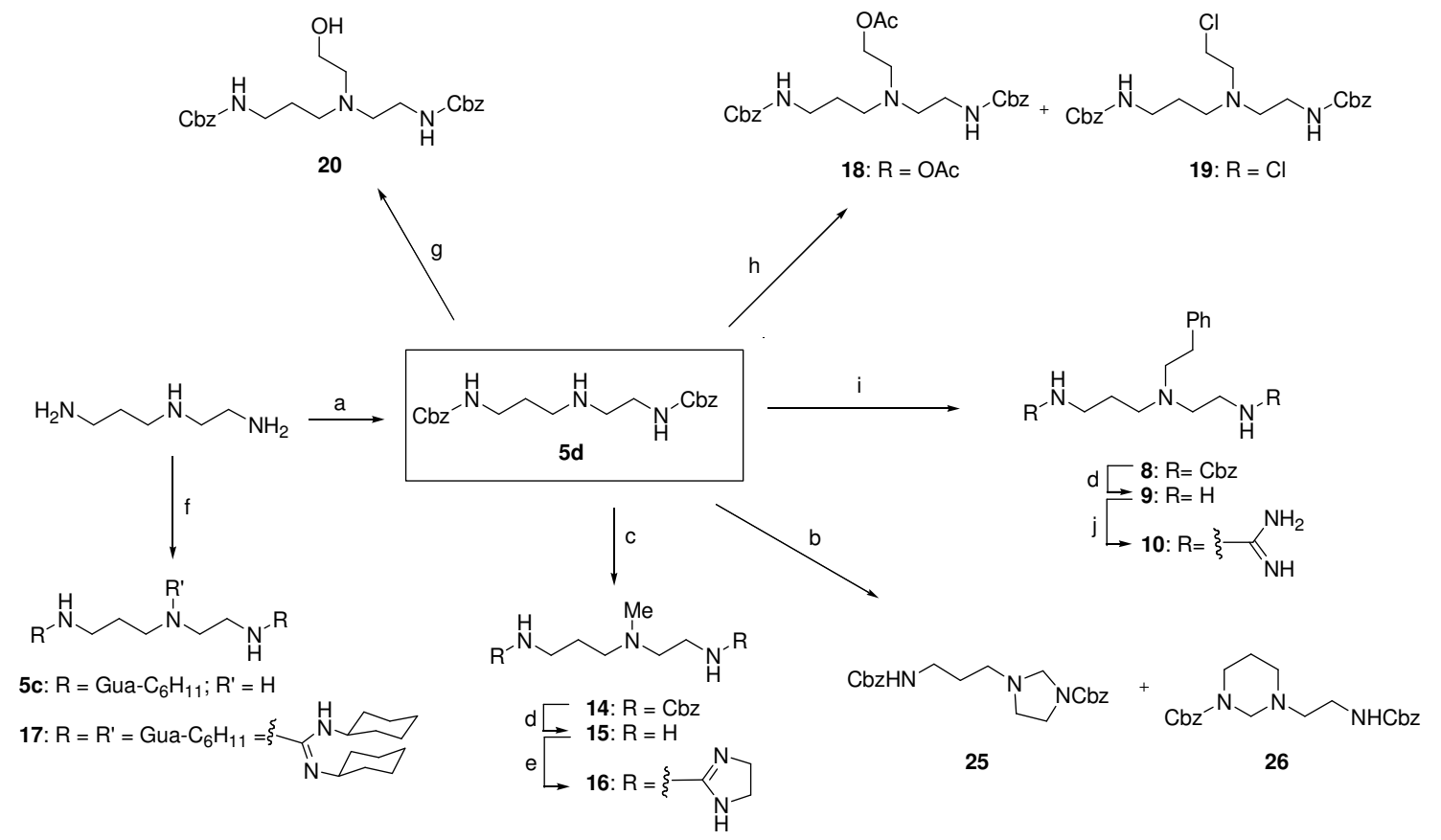

Scheme 1. Reagents and conditions. (a) $\mathrm{PhCH}_{2} \mathrm{CO}_{2} \mathrm{CN}$ (2 equiv.), $\mathrm{CH}_{2} \mathrm{Cl}_{2}$; (b) $\mathrm{HCHO}, \mathrm{NaBH}_{3} \mathrm{CN}, \mathrm{AcOH}$ (pH<7), $\mathrm{MeCN}$; (c) $\mathrm{HCHO}$, $\mathrm{NaBH}_{3} \mathrm{CN}, \mathrm{MeCN}\left(\mathrm{pH}>7\right.$ ); (d) $\mathrm{H}_{2}, \mathrm{Pd}-\mathrm{C} 10 \%, \mathrm{MeOH}, \mathrm{HCl} 1 \mathrm{M}$; (e) 2-methylmercapto-4,5-dihydroimidazole iodide, MeOH, reflux; (f) $\mathrm{DCC}$ $\mathrm{MeCN}$, rt; (g) 2-bromoethanol, MeCN, reflux; (h) chloroacetaldehyde (4 equiv.), $\mathrm{NaBH}(\mathrm{OAc})_{3}, \mathrm{AcOH}, \mathrm{MeCN}$, rt; (i) bromoethylbenzene, $\mathrm{K}_{2} \mathrm{CO}_{3}, \mathrm{CH}_{3} \mathrm{CN}$, reflux; (j) S-methylisothiouronium sulfate, $\mathrm{CH}_{3} \mathrm{CN}$, reflux.

Synthesis of the diphenyl derivatives (Scheme 2). Guanidines 31c and 32c were obtained by reaction of an ether solution of $\mathrm{N}$-(2,2'-diethoxyethyl)carbodiimide (prepared from $\mathrm{BrCN}$ and aminoacetaldehyde-diethylacetal) ${ }^{36}$ with 4,4'diaminodiphenylamine and 4,4'-diaminodiphenymethane in the presence of $\mathrm{CH}_{3} \mathrm{SO}_{3} \mathrm{H}$, respectively. Preparation of the 2-aminoimidazole 35 was carried out by base-catalysed cyclisation of the guanidine precursor 31c following the methodology of Munk et al.. ${ }^{36}$ In this reaction, two cyclisation products could potentially form: (1H-imidazol-2-yl)aryl-amine ("endocyclic" amino group) and 1-aryl-1H-imidazol-2-ylamine ("exocyclic" amino group). ${ }^{1} \mathrm{H}$ NMR spectrum of $\mathbf{3 5}$ showed a unique broad singlet for $4-\mathrm{H}$ and $5-\mathrm{H}$ imidazol protons at $6.76 \mathrm{ppm}$ whereas decoupled ${ }^{13} \mathrm{C}$ NMR spectrum showed a unique 
signal for both 4- and 5- imidazole carbons indicating the magnetic equivalence of these atoms. These data demonstrated that the expected product $\mathbf{3 5}$ with the endocyclic amino group was obtained (e.g. if the isomer with exocyclic amino group were obtained, a typical AB system would be observed for the 4- and 5-H imidazol protons).

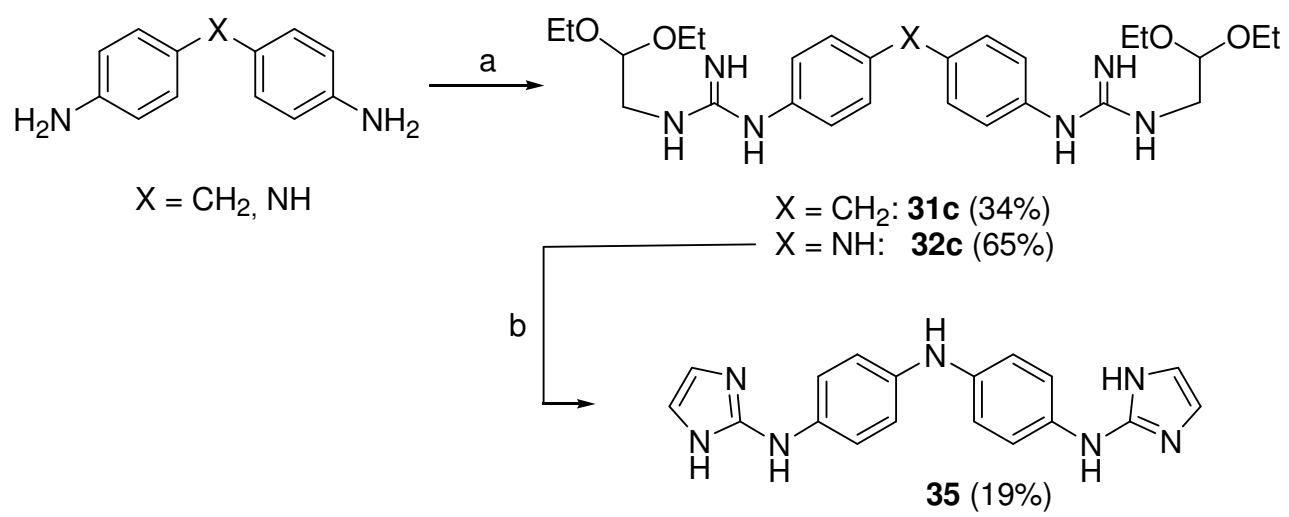<smiles>[R]Cc1ccc(C(=O)c2ccc(C(=O)[Pb])cc2)cc1</smiles>

Scheme 2. Reagents and conditions. (a) $\mathrm{N}$-(2,2'-diethoxyethyl)carbodiimide (2.2 equiv.); $\mathrm{CH}_{3} \mathrm{SO}_{3} \mathrm{H}$ (2 equiv.); EtOH, reflux, 23h; (b) 1) $6 \mathrm{M} \mathrm{HCl}$, rt, 3h, 2) $10 \% \mathrm{NaOH}$, rt, $1 \mathrm{~h}$; (c) NBS, $t$-BuOOH, $\mathrm{CCl}_{4}$, reflux; (d) tri- $n$-pentylphosphine (4 equiv.); PhMe, reflux, $24 \mathrm{~h}$.

Compound 37 has been previously described ${ }^{37}$ as a $\mathrm{B}_{2}$ bradykinin receptor antagonist. The reported procedure was quite lengthy so we designed a three steps synthesis starting from 4,4'-dimethylbenzophenone. Radicalar bromination of 4,4'dimethylbenzophenone with $\mathrm{NBS} / t-\mathrm{BuOOH} / \mathrm{CCl}_{4}$ allowed the formation of the dibromo-derivative compound $\mathbf{3 6}$ which was isolated by crystallisation from the reaction mixture (22\% yield). The low yield obtained could be explained by the formation of a mixture of mono- and poly-halogenated derivatives (e.g. three spots were observed by TLC of the crude reaction mixture). ${ }^{38}$ The bis-phosphonium compound $\mathbf{3 7}$ was obtained by nucleophilic substitution of the bromine atoms of $\mathbf{3 6}$ with an excess of tri- $n$-pentylphosphine in refluxing toluene. Tri- $n$-pentylphosphine was prepared by a 
modification of the procedure described by Davies et al. ${ }^{39}$ The reaction of an excess of bromopentane Grignard's reagent with phosphorous trichloride working at $-78{ }^{\circ} \mathrm{C}^{40}$ afforded the tri- $n$-pentylphosphine which was purified by fractional distillation.

Synthetic approach for the preparation of the piperazine-based bisguanidine and bis(2-aminoimidazoline) compounds is depicted in scheme 3. Aromatic nucleophilic substitution of 1-fluoro-4-nitrobenzene with the commercially available 1-(4-nitrophenyl)-piperazine in DMSO at $100{ }^{\circ} \mathrm{C}$ afforded $38 .^{41}$ Nitro groups were reduced by catalytic hydrogenation $(10 \% \mathrm{Pd}-\mathrm{C} / \mathrm{HCl} / \mathrm{MeOH})$ affording the amine $\mathbf{3 9}^{42}$. Introduction of the Boc-protected guanidine and imidazoline moieties (compounds 40a and 41a respectively) was carried out in good yield with $N, N^{\prime}$-di(tert-butoxycarbonyl)thiourea ${ }^{43}$ and $N, N^{\prime}$-di(tert-butoxycarbonyl)imidazoline-2-thione ${ }^{26}$ respectively. Removal of the Boc-protecting groups was accomplished by treatment with TFA, affording $40 \mathrm{~b}$ and 41b as their trifluoroacetate salts.

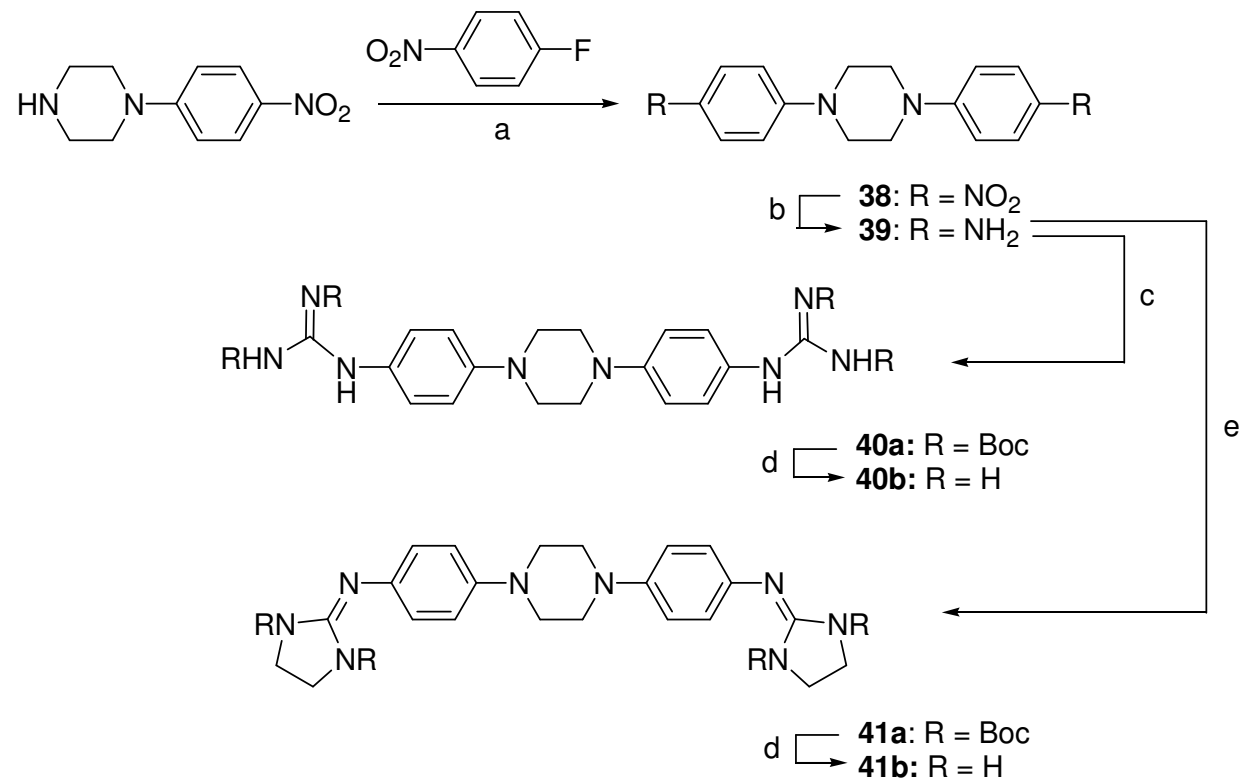

Scheme 3. Reagents and conditions. (a) DMSO, $100{ }^{\circ} \mathrm{C}, 60 \mathrm{~h}$ (73\%); (b) $\mathrm{H}_{2}$ (40 Psi), $10 \% \mathrm{Pd}-\mathrm{C}, \mathrm{HCl}$, $\mathrm{MeOH}$, rt (59\%); (c) $\mathrm{N}, \mathrm{N}^{\prime}$-bis(tert-butoxycarbonyl)-thiourea (2.2 equiv.), $\mathrm{HgCl}_{2}, \mathrm{Et}_{3} \mathrm{~N}, \mathrm{DMF}, 0^{\circ} \mathrm{C}$ then rt (73\%); (d) TFA, $\mathrm{CH}_{2} \mathrm{Cl}_{2}$ (88\%); (e) N,N'-bis(tert-butoxycarbonyl)imidazoline-2-thione (2.2 equiv.), $\mathrm{HgCl}_{2}, \mathrm{Et}_{3} \mathrm{~N}, \mathrm{DMF}, 0{ }^{\circ} \mathrm{C}$ then rt $(66 \%)$. 


\section{Biological results. In vitro anti-trypanosomal activity}

The results of the determination of anti-trypanosomal activity against bloodstream form trypomastigotes of T.b. rhodesisense (strain STIB 900) are reported in Tables 1 to 5. All compounds displayed dose-dependant activities against T.b. rhodesiense, with $\mathrm{IC}_{50}$ ranging from $0.022 \mu \mathrm{M}$ to $113 \mu \mathrm{M}$, and were selective for the parasite. Eight aliphatic (1b-d, 2b-d, 13 and 17) and 12 diphenyl derivatives (27b, 28a-b, 31b-c, 32a-c, 34, 37, 40b and 41b) showed an $\mathrm{IC}_{50}<1 \mu \mathrm{M}$. Among the latter, five compounds had an $\mathrm{IC}_{50}$ in the nanomolar range (1c, $\mathbf{1 d}, \mathbf{2 8 a}, \mathbf{2 8 b}$ and $\left.\mathbf{3 2 b}\right)$ with a selectivity index (SI) ranging from $13(\mathbf{1 d})$ to more than $5000(\mathbf{1 c})$.

Alkane and aza-alkane derivatives (Tables 1 and 2). The most potent compound within the alkane (Table 1) and aza-alkane (Table 2) derivative series was 1,9nonanediguanidine (1c) with $\mathrm{IC}_{50}=49 \mathrm{nM}$ and a remarkable selectivity for the parasite (SI > 5294). In these series, the guanidinium cation gave in general more active compounds (about 2 to 4-fold) than the 2-aminoimidazolinium counterpart (compare 1a-d / 2a-d). This was also true for the aza-alkane series (Table $2, \mathbf{5 a} / \mathbf{5 b}$ and $\mathbf{6 a} / \mathbf{6 b}$ ). Increasing the chain length of the methylene spacer $(n=6,8,9,12)$ between either guanidinium or 2-aminoimidazolinium cations tended to increase the activity with the following order: $\mathrm{n}=6<\mathrm{n}=8($ ca 30 -fold) $<\mathrm{n}=9 \sim \mathrm{n}=12$ (Table 1). Regarding the selectivity, the nine-methylene spacer (1c and 2c) gave the best SI (5294 and 71) in both series. Noteworthy was the greater activity displayed by the dicationic derivatives $\mathbf{1 b}$-d and $\mathbf{2 b}$-d with respect to their monocationic counterparts (Table 1). This behaviour was also observed for the aza-alkane compound $\mathbf{6 b}$ which was 3.5-fold more active than 7 (Table 2). 
Tables 1 around here ${ }^{44}$

Introduction of an unsubstituted nitrogen atom in the methylene chain (e.g. in the aza-alkane series, Table 2) tended to reduce the activity compared to alkyl spacer. This is exemplified by the activity of compounds $1 \mathbf{a}$ and $\mathbf{2 a}$ ( 8 and $19.3 \mu \mathrm{M}$ respectively) and their aza-analogues 5a and 5b (21.4 and $69.1 \mu \mathrm{M}$ respectively). Another interesting result was that of the dicyclohexylguanidine $\mathbf{5 c}\left(\mathrm{IC}_{50}=2.4 \mu \mathrm{M}\right)$ which was 9-fold more active than the guanidine analogue 5a $(21.4 \mu \mathrm{M})$. This result might reflect better pharmacokinetic properties of the more lipophilic derivative 5c (i.e. to cross biological membranes).

Tables 2 around here

The dicyclohexylguanidine compound $17\left(\mathrm{IC}_{50}=0.98 \mu \mathrm{M}\right)$ displayed the best activity and selectivity (SI > 82) of all the 3-aza-1,6-hexanediamine derivatives (Table 3). Again, it appeared that lipophilicity was an important factor for good activity. In this series, substitution of the secondary amino group with a phenethyl, 3(2-ethyl)indole or methyl group afforded molecules slightly more active than the parent compound (compare the activities of $\mathbf{1 0} / \mathbf{5 a}, \mathbf{1 1} / \mathbf{5 b}$ and $\mathbf{1 6} / \mathbf{5 b}) .{ }^{45}$ In addition, the amines protected with a carbobenzyloxy group $(\mathrm{Cbz})$ were more active than their free amino counterparts (compare 8/9, 12/13 and 14/15. Regarding the effect of the substituent on the secondary nitrogen in the Cbz-protected series, the following results, in order of decreasing activity, were obtained: indole $(13: 1 \mu \mathrm{M})>$ methyl $($ 14: $3.1 \mu \mathrm{M}) \sim$ phenethyl $(8: 3.88$ $\mu \mathrm{M})>\mathrm{CH}_{2} \mathrm{CH}_{2} \mathrm{OAc}($ 18: $7.1 \mu \mathrm{M})>\mathrm{CH}_{2} \mathrm{CH}_{2} \mathrm{OH}($ 20: $14 \mu \mathrm{M})$. 
Table 3 around here

Worth mentioning is the result obtained for the cyclic analogues $\mathbf{2 5}$ and $\mathbf{2 6}$ (Table 4), which showed the same range of activity as the parent compound $\mathbf{1 4}\left(\mathrm{IC}_{50}=3.1 \mu \mathrm{M}\right.$, Table 3) but a lower selectivity (SI $=27$ and 18.6 respectively, compared to 41 for 14$)$. This behaviour was also observed with the cyclic analogue $23(71.2 \mu \mathrm{M})$ which displayed the same activity as the aliphatic parent $\mathbf{5 b}(69.1 \mu \mathrm{M})$.

Table 4 around here

Diphenyl derivatives (Table 5). In this series of bisguanidine and bis(2aminoimidazoline) diphenyl analogues (Entry 1-17), best activities were observed for the compounds bearing a guanidinium group (from 3- to 10-fold with respect to the imidazoline analogues). However, the 2-aminoimidazoline derivatives displayed, in general, better selectivity than the guanidine counterparts (compare the activity and selectivity of $\mathbf{3 1 b} / \mathbf{2 7 b}, \mathbf{3 2 b} / \mathbf{2 8 b}, \mathbf{3 4} / \mathbf{2 9 b}$ and $\mathbf{3 2 a} / \mathbf{2 8 a})$. In addition, replacement of the guanidine or 2-aminoimidazoline with a 2-aminoimidazole nucleus (compound $\mathbf{3 5}$, entry 18) produced a loss of activity of 20 - and 63-fold compared to $\mathbf{2 8 b}$ and $\mathbf{3 2 b}$ respectively. Interestingly, the very lipophilic bis-phosphonium benzophenone derivative 37 showed a trypanocidal activity $\left(\mathrm{IC}_{50}=0.414 \mu \mathrm{M}\right)$ similar to that of the bisguanidinium diphenylketone $34(0.206 \mathrm{mM})$ and a better selectivity $(\mathrm{SI}=28.5$ versus 13.1).

Notable is the effect of the $\mathrm{N}$-substitution of the imidazoline and guanidine moieties (i.e. Boc, $\left.\mathrm{CH}_{2} \mathrm{CH}(\mathrm{OEt})_{2}\right)$. Boc protection afforded less active compounds compared to unprotected counterparts (compare 27a/27b, 29a/29b, 31a/31b, 32a/32b, 33a/ 33b and 
40a/40b) with the exception of 28 and 30 in which the Boc substituents produced a 1.4 and 12-fold increase in activity respectively $\left(\mathrm{IC}_{50}=0.048\right.$ and $2.6 \mu \mathrm{M}$ respectively) compared to the free imidazolinium cation $\left(\mathrm{IC}_{50}=0.069\right.$ and $32.4 \mu \mathrm{M}$ respectively). Moreover, the Boc substituents seemed to give somewhat less selective compounds (SI $=202$ and 3072 for $\mathbf{2 8 a}$ and $\mathbf{2 8 b}$ respectively; SI $=7.9$ and 29.5 for $\mathbf{3 2 a}$ and $\mathbf{3 2 b}$ ). On the contrary, the 1,1-diethoxyethane substituent produced a great increase in selectivity, superior to 26- and 32-fold for 31c and 32c respectively, with only a slight loss in activity (2- and 10-fold respectively) compared to the unsubstituted parent compounds 31b and 32b.

Table 5 around here

Regarding the bridge linking both phenyl rings, the same behaviour was observed for the guanidinium and 2-aminoimidazolinium series, i.e. $\mathrm{NH}>>\mathrm{CH}_{2}>\mathrm{CO}>\mathrm{SO}_{2}$ in order of decreasing activity (compare $\mathbf{2 7 b}-\mathbf{3 0 b}$ and $\mathbf{3 1 b}-\mathbf{3 3 b}, \mathbf{3 4}$ ). When a piperazine moiety was used as bridge between both phenyl rings (Table 5, entry 21-25), the 2aminoimidazolinium compound $41 \mathrm{~b}$ showed the best activity $(0.118 \mu \mathrm{M})$ and also a 5 times higher selectivity $(\mathrm{SI}=881)$ with respect to the guanidinium analogue $(\mathrm{SI}=172)$.

\section{Discussion}

Some of the compounds described in this manuscript were available in our in-house library. Since few of these molecules had been previously reported in the literature for their anti-trypanosomal activity (e.g. $\mathbf{1 d},{ }^{5} \mathbf{3 1 b},{ }^{8} \mathbf{3 3 b ^ { 1 0 }}$ ), we anticipated that our compounds would display trypanocidal action. Indeed, simple aliphatic diguanidines 
were potent and selective trypanocides, with $3 \mathbf{c}(\mathrm{SI}>5294)$ being more selective than the control melarsoprol $(\mathrm{SI}=3456)$. The potency of $\mathbf{3 c}$ is to be compared with that of synthalin (1,10-decanediguanidine $)^{7}$ or 1,11-undecanediamidine, a trypanocidal drug which proved able to cure mice and rabbits infected with a strain of T.b. rhodesiense. $^{6}$ The 1,9-nonanediguanidine $3 \mathbf{c}$ could be considered as the bio-isostere of 1,11undecanediamidine with the supplementary amino groups of the guanidine moieties playing the role of the two supplementary methylene units, thus keeping approximately the same chain length in both molecules.

In those series, the guanidine moiety afforded in general better trypanocidal drugs than the 2-aminoimidazoline one. Moreover, the presence of two cations was required for potent activity, which is in agreement with the results previously obtained by King et al. ${ }^{6}$ This assumption could probably be extended to the diphenyl series, according to the previous findings reported for aromatic diamidines and diguanidines, ${ }^{6,9,10}$ although this hypothesis was not tested here because mono-cationic aromatic compounds were not available in our library.

For short methylene chains $(n=5,6,7)$, introduction of a secondary nitrogen atom into the alkyl spacer afforded less active molecules although further substitution of this nitrogen could increase slightly the activity (compounds 8-20). Conformational restriction of the aza-alkane molecules did not affect nor increase the trypanocidal action compared to their linear analogues (compounds $\mathbf{2 3}, \mathbf{2 5}$ and 26). The importance of lipophilicy of these molecules, facilitating drug uptake by the parasite by passive diffusion, was exemplified by the higher anti-trypanosomal activity of $\mathbf{5 c}$ with respect to $5 a$.

The most interesting results probably came from the diphenyl series with a NH bridge. The bis(2-aminoimidazoline) derivative $\mathbf{2 8 b}$ was extremely potent $\left(\mathrm{IC}_{50}=69\right.$ 
$\mathrm{nM})$ and also highly selective for the parasite $(\mathrm{SI}=3072)$. The Boc-protected counterpart 28a had the same range of activity but a lower selectivity index (SI = 202). This result in particular might be relevant because of the higher lipophilicity of the Bocprotected compound 28a. Late-stage cases of HAT involve CNS infection and hence, require drugs able to cross the blood-brain barrier. However, the Boc-protecting group is probably stable in the conditions of the in vitro assay but potentially could be metabolised in vivo to afford the unprotected derivative $\mathbf{2 8 b}$.

Changing the 2-aminoimidazolinium cations for guanidinium ones led to the most active compound of this screening: 32b $(22 \mathrm{nM}, \mathrm{SI}=29.5)$. The nature of the bridge linking both phenyl rings had a clear influence on the trypanocidal action of these compounds. Electron-donating groups such as $\mathrm{NH}$, piperazine or $\mathrm{CH}_{2}$ afforded better trypanocides than electron-withdrawing groups such as $\mathrm{C}=\mathrm{O}$ or $\mathrm{SO}_{2}$. Such behaviour was consistent with the findings of Donkor et al. in the pentamidine congener series where electron-rich phenyl groups (e.g. phenoxy) afforded better trypanocides than electron-poor phenyl rings (e.g. acetylated aniline or pyridine). ${ }^{15}$

If we compare the different cationic species studied (i.e. guanidinium, 2aminoimidazolinium, phosphonium), the good activity and selectivity displayed by the bis-phosphonium derivative $37\left(\mathrm{IC}_{50}=0.414 \mu \mathrm{M}\right.$, SI $\left.=28.5\right)$ is of particular interest. These results suggest that lipophilic bis-phosphonium diphenyl derivatives might be a good alternative (with potentially better pharmacokinetic properties) to the guanidine or 2-aminoimidazoline derivatives. With respect to the guanidine cation, $\mathrm{N}$-substitution with a diethoxyethane moiety afforded highly selective anti-trypanosomal agents (SI > 754 and 767 for 31c and 32c respectively).

Anti-trypanocidal efficacy of a drug depends on its effective uptake by the parasite. It is known that diamidines such as pentamidine, which have very slow rate of diffusion 
across biological membranes, can be transported into the cell by a P2-amino-purine transporter that specifically recognises the main $\mathrm{H}_{2} \mathrm{~N}-\mathrm{C}\left(\mathrm{R}_{1}\right)=\mathrm{NR}_{2}$ motif. $^{46,47}$ The guanidine molecules reported here also present this recognition motif. In the case of the diphenyl derivatives, most of the Boc-protected molecules (i.e. the most lipophilic) showed a weaker activity than the charged, unprotected, guanidinium analogues. This might account for a more efficient transport of the unprotected derivatives through the P2 transporter, although affinity assays for this transporter remain to be done.

It is still too early to propose a mode of action of the compounds presented here and further studies are needed. However, a number of dicationic molecules belonging to the diamidine family (e.g. pentamidine) are known to bind to the minor-groove of DNA and their antiprotozoal activity is thought to be the result of that interaction (e.g. inhibition of DNA dependant enzymes or inhibition of transcription). ${ }^{48-50}$ In a recent article, Donkor et al. studied the trypanocidal activity of a series of conformationally restricted congeners of pentamidine. ${ }^{15}$ Although a direct correlation between the DNA binding affinity and the trypanocidal activity was not observed, the authors concluded that compounds with strong DNA affinity generally showed good trypanocidal activity in that series. In particular, $N, N^{\prime}$-bis(4-amidinophenyl)piperazine (Figure 1) and $N, N^{\prime}$ bis(4-imidazolinophenyl)piperazine were the most potent trypanocides and also the strongest DNA binders in this series. According to the results of Donkor et al., we might expect good DNA binding affinity for compounds $\mathbf{4 0 b}$ and $\mathbf{4 1 b}$, which are the guanidine and 2-aminoimidazoline analogues of these congeners respectively (vide infra). However, this hypothesis will need experimental confirmation.

Several compounds presented in this paper were first and foremost studied for different activities on the CNS (i.e. $\alpha_{1}$-adrenergic antagonism, $\mathrm{I}_{2}$-imidazoline binding site affinity or analgesic properties). The knowledge of these interactions (i.e. possible 
side effects) is of importance because useful anti-trypanocidal agents are expected to penetrate the CNS to cure late-stage cases of HAT. The diphenyl compounds (Table 5, entries 5-8 and 12-15) present $\alpha_{1}$-adrenergic antagonist activity in various tissues. ${ }^{26,51}$ In particular, the blood pressure and heart rate responses of two compounds (29b and $\mathbf{3 1 b}$ ) had been tested on rats in vivo, suggesting a smaller magnitude of cardiovascular effects than the $\alpha_{1}$-adrenergic antagonist Doxazosin at the same dose. ${ }^{52}$ On the other hand, the alkane derivatives (Table 1, 1a-d and 2a-d) showed a moderate to good affinity for the $\mathrm{I}_{2}$-imidazoline binding sites and $\alpha_{2}$-adrenoceptors in human brain membranes. ${ }^{27}$ Finally, several aza-alkane derivatives (Tables 2 and 3: 4a-b, 5a-b, 6a-b, 7, 10, 11, 23) were tested for analgesic activity in mice. ${ }^{28}$ These data are relevant and should be taken into consideration when choosing possible lead compounds for in vivo assays.

\section{Conclusion}

We have reported here the screening for trypanocidal activity against T.b. rhodesiense of an in-house library of 62 compounds [i.e. alkane, diphenyl and azaalkane bisguanidine and bis(2-aminoimidazoline)] which were chosen for their structural similarity to the trypanocidal agents synthalin (1,10-decanediguanidine), and 4,4'-diguanidinodiphenylmethane, and the polyamine $N^{1}$-(3-amino-propyl)-propane1,3-diamine respectively. The original synthetic procedure for the preparation of 21 of these compounds was also reported.

The results of the determination of in vitro anti-trypanosomal activity allowed drawing some conclusions about the SAR of these series of molecules. Most compounds displayed low micromolar anti-trypanosomal activity with five of them presenting a nanomolar inhibitory action on the parasite (1c, 1d, 28a, 28b and 32b). Few of these compounds, which showed an excellent in vitro activity as well as high 
selectivity, e.g. 1c $\left(\mathrm{IC}_{50}=49 \mathrm{nM}\right.$; SI > 5294), 28b $\left(\mathrm{IC}_{50}=69 \mathrm{nM} ; \mathrm{SI}=3072\right), \mathbf{3 2 b}\left(\mathrm{IC}_{50}\right.$ $=22 \mathrm{nM} ; \mathrm{SI}=29.5), \mathbf{4 1} \mathbf{b}\left(\mathrm{IC}_{50}=118 \mathrm{nM} ; \mathrm{SI}=881\right)$ are promising lead compounds for anti-trypanosomal chemotherapy. The results of in vivo activity of these molecules will be reported in due course.

Tropical diseases mainly affect third-world countries which usually lack research capacities and financial resources for investigation. The lack of available funds and research in this field put into light the importance of screening in-house libraries of molecules already available in order to save time and money in the discovery of new lead compounds for neglected diseases like HAT.

\section{Experimental Section}

Chemistry. All reaction solvents were purchased anhydrous and used as received. Other solvents used were reagent grade. Reactions were monitored by TLC using precoated silica gel 60 F254 plates. Chromatography was performed either with silica gel $60 \mathrm{PF}_{254}$ (particle size 40-63 $\mu \mathrm{m}$ ) or with a medium pressure chromatography system using KP-Sil ${ }^{\mathrm{TM}} 40 \mathrm{~S}$ or $40 \mathrm{M}$ cartridges (particle size $32-63 \mu \mathrm{m}, 60 \AA ̊$ ). All reactions requiring anhydrous conditions or an inert atmosphere were performed under a positive pressure of $\mathrm{N}_{2}$. ${ }^{1} \mathrm{H} \mathrm{NMR}$ and ${ }^{13} \mathrm{C} \mathrm{NMR}$ spectra were recorded at 200 and $50 \mathrm{MHz}$ respectively, unless otherwise noted. Chemical shifts of the ${ }^{1} \mathrm{H}$ NMR spectra were internally referenced to the residual proton resonance of the deuterated solvents: $\mathrm{CDCl}_{3}$ (7.26 ppm), $\mathrm{D}_{2} \mathrm{O}(\delta 4.6 \mathrm{ppm}), \mathrm{CD}_{3} \mathrm{OD}(3.49 \mathrm{ppm})$ and DMSO ( $\left.\delta 2.49 \mathrm{ppm}\right)$. Chemical shifts of ${ }^{13} \mathrm{C}$ NMR and ${ }^{31} \mathrm{P}$ spectra were referenced with a capilar of DMSO-d $6(\delta 39.5$ ppm) and $\mathrm{H}_{3} \mathrm{PO}_{4}(\delta 0 \mathrm{ppm})$ respectively. IR spectra were recorded as $\mathrm{KBr}$ pellets or neat. Melting points were determined with a Reichert-Jung Thermovar apparatus and 
are uncorrected. Mass spectra were recorded on a Hewlett Packard Series 1100 MSD spectrometer (ES, APCI) and on a VG Autospec spectrometer (FAB). Elemental analysis was performed on a Heraeus CHN-O Rapid analyser. Analytical results were within $\pm 0.4 \%$ of the theoretical values unless otherwise noted. Analytical HPLC was

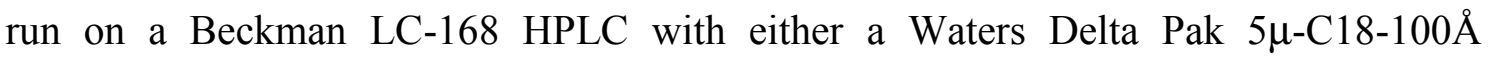

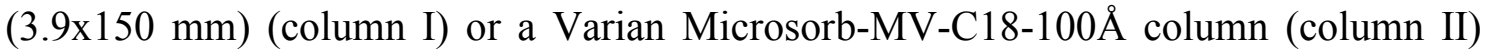
using the following conditions: gradient time $=40 \mathrm{~min}$ and $15 \mathrm{~min}$ for columns I and II respectively, $\mathrm{H}_{2} \mathrm{O} / \mathrm{CH}_{3} \mathrm{CN}(100: 0 \rightarrow 0: 100)($ TFA $0.1 \%$ ), flow rate $=1 \mathrm{~mL} / \mathrm{min}, \lambda=214$ and $254 \mathrm{~nm}$. Preparative HPLC (compounds 5c and 17) was carried out using a Waters Deltaprep apparatus with a Waters prepak®-RCM Base column and detection at 214 nm.

Compounds 1a, 1b-1d, 2a, 2b, 2c, 2d, 3b, 3c, 3d, 4a- 6a, ${ }^{53} 4 b, 5 b, 5 d, 6 b, 7,8,9,11$, 12, 13, 21, 22, 23, 24, 27a-33a, 27b-33b and 34 were prepared as previously reported. $^{26-28,53}$

N-\{3-[(2-Guanidino-ethyl)-phenethyl-amino]-propyl\}-guanidine (10). A solution of $9(0.5 \mathrm{mmol})$ and S-methylisothiouronium sulfate $(148 \mathrm{mg}, 0.53 \mathrm{mmol})$ in dry $\mathrm{MeOH}(7 \mathrm{~mL})$ was heated for $12 \mathrm{~h}$ at reflux. The solvent was removed by reduce pressure and the crude product dissolved in a mixture of $\mathrm{H}_{2} \mathrm{O} / \mathrm{EtOH}$ was treated with a few drops of $5 \% \mathrm{H}_{2} \mathrm{SO}_{4}$. The solution was allowed to stand 3 days in the fridge and the supernatant was discarded. Acetone was added and the oily residue was triturated with a spatula until the product crystallised. The solid was dried in vacuo affording $\mathbf{1 0}$ as a highly hygroscopic colorless solid (104 mg, $46 \%) .{ }^{1} \mathrm{H}$ NMR $\left(\mathrm{D}_{2} \mathrm{O}\right) \delta$ 7.3-7.0 (m, 5H); 
3.6-2.8 (m, 12H); $1.87(\mathrm{~m}, 2 \mathrm{H}) ;{ }^{13} \mathrm{C}$ NMR $\left(\mathrm{D}_{2} \mathrm{O}\right) \delta 155.9(\mathrm{br}) ; 135.0 ; 128.1 ; 127.7$; 126.4; 53.0; 50.6; 49.9; 37.1; 35.4; 28.2; 22.7. LRMS (ES $\left.{ }^{+}\right)$m/e: 307 [(M+H)]; $100 \%$ ].

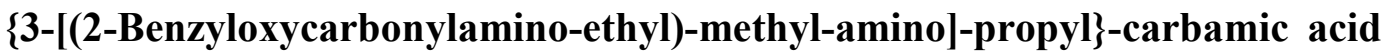
benzyl ester (14). $\mathrm{NaBH}_{3} \mathrm{CN}(100 \mathrm{mg}, 1.49 \mathrm{mmol})$ was added to a solution of amine $\mathbf{5 d}$ (443 mg, $1.15 \mathrm{mmol}$ ) and $37 \%$ aqueous formaldehyde $(0.4 \mathrm{~mL}, 4.6 \mathrm{mmol})$. The reaction was stirred $4 \mathrm{~h}$ at room temperature and the solvents were removed by reduce pressure. The crude residue was partitioned between $\mathrm{CHCl}_{3}$ and water. The organic phase was collected and the aqueous phase was extracted 3 times with $\mathrm{CHCl}_{3}$. Organic extracts were washed with brine, dried $\left(\mathrm{Na}_{2} \mathrm{SO}_{4}\right)$ and concentrated by reduce pressure. Flash chromatography (40S cartridge) with $\mathrm{CH}_{2} \mathrm{Cl}_{2} / \mathrm{MeOH}$ (95:5) afforded the methylated amine 14 as a colorless solid (236 mg, $51 \%$ ); mp 60-62 ${ }^{\circ} \mathrm{C}$; IR (KBr) $v$ $3300,2900,2725,1665,1515,1250,1120,960,720,685,670 \mathrm{~cm}^{-1} ;{ }^{1} \mathrm{H}$ NMR $\left(\mathrm{CDCl}_{3}\right)$ $\delta$ 7.4-7.2 (m, 10H); $5.6(\mathrm{br}, \mathrm{NH}) ; 5.4(\mathrm{br}, \mathrm{NH}) ; 5.07(\mathrm{~s}, 2 \mathrm{H}) ; 5.05(\mathrm{~s}, 2 \mathrm{H}) ; 3.3-3.1(\mathrm{~m}$, $4 \mathrm{H}) ; 2.5-2.3(\mathrm{~m}, 4 \mathrm{H}) ; 2.17(\mathrm{~s}, 3 \mathrm{H}) ; 1.62$ (quint, $2 \mathrm{H}, J=6 \mathrm{~Hz}) ;{ }^{13} \mathrm{C} \mathrm{NMR}\left(\mathrm{CDCl}_{3}\right) \delta$ $157.1 ; 137.3 ; 137.2 ; 129.0 ; 128.6 ; 128.5 ; 67.1 ; 67.0 ; 57.3 ; 55.9 ; 42.2 ; 40.1 ; 38.9 ; 27.4$ LRMS $\left(\mathrm{ES}^{+}\right)$m/e: $400\left[(\mathrm{M}+\mathrm{H}), 100 \%\right.$; Anal. $\left(\mathrm{C}_{22} \mathrm{H}_{29} \mathrm{~N}_{3} \mathrm{O}_{4}\right) \mathrm{C}, \mathrm{H}, \mathrm{N}$.

\section{$N^{1}$-(2-Amino-ethyl)- $N^{1}$-methyl-propane-1,3-diamine}

(15). Catalytic hydrogenation of a suspension of $14(230 \mathrm{mg}, 0.57 \mathrm{mmol}), 10 \% \mathrm{Pd}-\mathrm{C}(23 \mathrm{mg})$ and $1 \mathrm{M}$ $\mathrm{HCl}(1 \mathrm{~mL})$ in $\mathrm{MeOH}(30 \mathrm{~mL})$ under a 36 Psi hydrogen pressure for $24 \mathrm{~h}$ at room temperature afforded the $\mathrm{HCl}$ salt of $\mathbf{1 5}$ as a colorless oil (118 mg, quantitative). ${ }^{1} \mathrm{H}$ $\operatorname{NMR}\left(\mathrm{D}_{2} \mathrm{O}\right) \delta 3.0-2.8(\mathrm{~m}, 4 \mathrm{H}) ; 2.58(\mathrm{t}, 2 \mathrm{H}, J=6.8 \mathrm{~Hz}) ; 2.46(\mathrm{t}, 2 \mathrm{H}, J=7.6 \mathrm{~Hz}) ; 2.16$ $(\mathrm{s}, 3 \mathrm{H}) ; 1.74$ (quint, $2 \mathrm{H}, J=7.6 \mathrm{~Hz}) ;{ }^{13} \mathrm{C} \mathrm{NMR}\left(\mathrm{D}_{2} \mathrm{O}\right) \delta 54.8(\mathrm{t}) ; 54.5(\mathrm{t}) ; 41.0(\mathrm{q}) ; 38.5$ $(\mathrm{t}) ; 37.0(\mathrm{t}) ; 24.5(\mathrm{t}) ; \mathrm{LRMS}\left(\mathrm{APCI}^{+}\right)$m/e 132 [(M+H), $100 \%$. Anal. $\left(\mathrm{C}_{6} \mathrm{H}_{20} \mathrm{~N}_{3} \mathrm{Cl}_{3} / 0.3\right.$ $\mathrm{H}_{2} \mathrm{O}$ ) calcd: C, 29.47; H, 8.49; N, 17.19; found: C, 29.35; H, 8.40; N, 17.00. 


\section{$N, N^{\prime}$-di[2-(4,5-dihydro-1H-imidazol-2-ylamino)-ethyl]- $N^{\prime}$-methyl-propane-}

1,3-diamine (16). A solution of $15(110 \mathrm{mg}, 0.84 \mathrm{mmol})$, 2-methylmercapto-4,5dihydro-1H-imidazole iodide $(410 \mathrm{mg}, 1.76 \mathrm{mmol})$ in EtOH $(10 \mathrm{~mL})$ was heated $24 \mathrm{~h}$ at reflux (CAUTION: the noxious gas $\mathrm{CH}_{3} \mathrm{SH}$ is evolved during the reaction and it should be trapped with a concentrated aqueous $\mathrm{NaOH}$ solution). The solvent was removed by reduce pressure and the crude compound was purified by formation of its picrate salt: a hot solution of picric acid ( $400 \mathrm{mg}$ in $5 \mathrm{~mL} \mathrm{H}_{2} \mathrm{O}$ ) was added to the hot reaction mixture and the flask was allowed to stand in the fridge for one week. The crystals were collected by filtration and rinsed successively with water, hexane and $\mathrm{Et}_{2} \mathrm{O}$. Picrate of 16: yellow solid (302 mg, $53 \%$ ); mp 81-83 ${ }^{\circ} \mathrm{C}$; ${ }^{1} \mathrm{H}$ NMR (400MHz, DMSO-d 6$) \delta 9.94$ (br s, 1H); $9.25($ br s, $1 \mathrm{H}) ; 8.54(\mathrm{~s}, 4 \mathrm{H}) ; 8.18(\mathrm{t}, 1 \mathrm{H}, J=5.7 \mathrm{~Hz}) ; 8.13(\mathrm{t}, 1 \mathrm{H}, J=4.8$ $\mathrm{Hz}) ; 7.65(\mathrm{br}, 1 \mathrm{H}) ; 3.80(\mathrm{~s}, 3 \mathrm{H}) ; 3.58(\mathrm{~s}, 4 \mathrm{H}) ; 3.55(\mathrm{~s}, 4 \mathrm{H}) ; 3.1(\mathrm{~m}, 4 \mathrm{H}) ; 2.8-2.7(\mathrm{~m}, 4 \mathrm{H})$; $1.8(\mathrm{br}, 2 \mathrm{H}) ;{ }^{13} \mathrm{C}$ NMR (50 MHz, DMSO-d 6$) \delta 170.5 ; 160.9$ (s); 159.4 (s); 141.5 (s); $125.3(\mathrm{~d}) ; 124.8(\mathrm{~s}) ; 53.6(\mathrm{br}, \mathrm{t}) ; 53.0(\mathrm{t}) ; 45.2(\mathrm{t}) ; 42.6(\mathrm{t}) ; 40.2(\mathrm{q}) ; 37.2(\mathrm{t}) ;$ LRMS $\left(\mathrm{FAB}^{+}\right)$m/e $268[(\mathrm{M}+\mathrm{H})]$. Anal. $\left(\mathrm{C}_{24} \mathrm{H}_{31} \mathrm{~N}_{13} \mathrm{O}_{14}\right) \mathrm{C}, \mathrm{H}, \mathrm{N}$.

3-Azahexane-1,7-(N,N'-dicyclohexyl)diguanidine (5c). A solution of 3-(2aminoethylamino)propylamine $(1 \mathrm{~mL}, 8.5 \mathrm{mmol})$ and DCC $(3.7 \mathrm{~g}, 17.9 \mathrm{mmol})$ in dry $\mathrm{CH}_{3} \mathrm{CN}(25 \mathrm{~mL})$ was stirred 4 days at room temperature under argon atmosphere. The solvent was removed by reduce pressure and the crude oil was dissolved in $\mathrm{Et}_{2} \mathrm{O}$. A current of $\mathrm{HCl}_{\mathrm{g}}$ was bubbled into the solution for $2 \mathrm{~min}$. The white precipitate was collected, rinsed with $\mathrm{Et}_{2} \mathrm{O}$ and dried in vacuo affording a mixture of the di- and trisubstituted compounds $\mathbf{5 c}$ and $\mathbf{1 7}$ which were separated by preparative HPLC using the following eluent system: $\mathrm{H}_{2} \mathrm{O} / \mathrm{CH}_{3} \mathrm{CN}(100: 0 \rightarrow 0: 100)$ (TFA $\left.0.1 \%\right)$. Trifluoroacetate of 5c: white solid; mp 88-93 ${ }^{\circ} \mathrm{C} ;{ }^{1} \mathrm{H}$ NMR $\left(400 \mathrm{MHz}, \mathrm{CDCl}_{3}\right) \delta 3.45$ (t, $2 \mathrm{H}, J=6.3 \mathrm{~Hz}$ ); 3.6-3.25 (m, 10H); $3.18(\mathrm{t}, 2 \mathrm{H}, J=7 \mathrm{~Hz}) ; 2.95($ br t, $2 \mathrm{H}) ; 1.82(\mathrm{q}, 2 \mathrm{H}, J=7.8 \mathrm{~Hz}) ; 1.69$ 
(br s, $8 \mathrm{H}) ; 1.60$ (br d, 8H); $1.46($ br d, $4 \mathrm{H}) ; 1.16(\mathrm{t}, 16 \mathrm{H}, J=10 \mathrm{~Hz}) ; 1.0(\mathrm{br} \mathrm{m}, 5 \mathrm{H}) ;{ }^{13} \mathrm{C}$ NMR (100 MHz, $\left.\mathrm{CDCl}_{3}\right) \delta 163.7$ (TFA); 154.0 (s); 154.0 (s); 117.6 (TFA); 52.6 (d); $52.5(\mathrm{~d}) ; 47.3(\mathrm{t}) ; 46.5(\mathrm{t}) ; 39.3(\mathrm{t}) ; 38.9(\mathrm{t}) ; 33.4(\mathrm{t}) ; 33.4(\mathrm{t}) ; 26.5(\mathrm{t}) ; 25.8(\mathrm{t}) ; 25.7(\mathrm{t})$ LRMS $\left(\mathrm{ES}^{+}\right) \quad m / e$ 265,9 [(M+2H), $100 \%$ \% 644.6 [(M+TFA)]; 758.6 [(M+2TFA)]; HPLC (column II): $\mathrm{R}_{\mathrm{t}}=9.37 \mathrm{~min}(100 \%)$.

3-Azahexane-1,3,7-(N,N'-dicyclohexyl)triguanidine (17). Trifluoroacetate of 17: white flocculent solid. ${ }^{1} \mathrm{H}$ NMR (500 MHz, $\left.\mathrm{CD}_{3} \mathrm{OD}\right)$ $\delta 3.73-3.60(\mathrm{~m}, 8 \mathrm{H}) ; 3.56-3.44$ $(\mathrm{m}, 6 \mathrm{H}) ; 2.14-1.8(\mathrm{~m}, 30 \mathrm{H}) ; 1.7-1.3(\mathrm{~m}, 32 \mathrm{H}) ;{ }^{13} \mathrm{C} \mathrm{NMR}\left(125 \mathrm{MHz}, \mathrm{CD}_{3} \mathrm{OD}\right) \delta 160.1$ $(\mathrm{s}) ; 154.2(\mathrm{~s}) ; 56.0(\mathrm{~d}) ; 52.6(\mathrm{~d}) ; 52.6(\mathrm{~d}) ; 49.8(\mathrm{t}) ; 47.7(\mathrm{t}) ; 39.9(\mathrm{t}) ; 39.7(\mathrm{t}) ; 34.5(\mathrm{t})$ $\left.33.9(\mathrm{t}) ; 33.9(\mathrm{t}) ; 28.2(\mathrm{t}) ; 26.2(\mathrm{t}) ; 26.2(\mathrm{t}) ; 26.1(\mathrm{t}) ; 26.1(\mathrm{t}) ; 26.0(\mathrm{t}) ; \mathrm{LRMS}_{(\mathrm{ES}}{ }^{+}\right) m / e$ $369[(\mathrm{M}+2 \mathrm{H}), 100 \%] ; 246.5[(\mathrm{M}+3 \mathrm{H})]$; HPLC (column I): $\mathrm{R}_{\mathrm{t}}=30.55 \min (99.58 \%)$.

\section{\{3-[(2-Benzyloxycarbonylamino-ethyl)-(2-chloro-ethyl)-amino]-propyl\}-}

carbamic acid benzyl ester (19). Chloroacetaldehyde (50\% in water, $1.5 \mathrm{~mL}, 11.6$ mmol) was added to a solution of $\mathbf{5 d}(1.11 \mathrm{~g}, 2.9 \mathrm{mmol})$ in $\mathrm{CH}_{3} \mathrm{CN}(20 \mathrm{~mL})$. After a few minutes, $\mathrm{AcOH}(0.5 \mathrm{~mL}, 8.5 \mathrm{mmol}))$ was added, followed $5 \mathrm{~min}$ later by $\mathrm{NaBH}(\mathrm{OAc})_{3}(1.24 \mathrm{~g}, 5.8 \mathrm{mmol})$. The reaction mixture was stirred for $4 \mathrm{~h}$ at room temperature adjusting the $\mathrm{pH}$ to 5-6 with $\mathrm{AcOH}$ during the course of the reaction. The reaction was quenched by careful addition of $5 \% \mathrm{NaHCO}_{3}$ and diluted with $\mathrm{CH}_{2} \mathrm{Cl}_{2}$. The organic phase was separated and the aqueous phase was extracted 3 times with $\mathrm{CH}_{2} \mathrm{Cl}_{2}$. Combined organic extracts were washed with brine, dried $\left(\mathrm{Na}_{2} \mathrm{SO}_{4}\right)$ and concentrated by reduce pressure. Chromatography (40M cartridge) with petroleum ether/acetone (80:20) yielded the acetyl side-product 18 (16\%) and the expected chloroderivative 19 as an oil that solidified as a yellowish pasty residue (450 mg, $35 \%$ ); IR (KBr): v: $1680 ; 1415 ; 1240 ; 755 ; 713 ; 675 \mathrm{~cm}^{-1} ;{ }^{1} \mathrm{H}$ NMR $\left(\mathrm{CDCl}_{3}\right) \delta 7.29$ (br s, $\left.10 \mathrm{H}\right)$; $5.67(\mathrm{br}, \mathrm{NH}) ; 5.60(\mathrm{br}, \mathrm{NH}) ; 5.09(\mathrm{~s}, 2 \mathrm{H}) ; 5.08(\mathrm{~s}, 2 \mathrm{H}) ; 3.43(\mathrm{t}, 2 \mathrm{H}, J=6.1 \mathrm{~Hz}) ; 3.3-3.1$ 
$(\mathrm{m}, 4 \mathrm{H}) ; 2.68(\mathrm{t}, 2 \mathrm{H}, J=6.3 \mathrm{~Hz}) ; 2.6-2.4(\mathrm{~m}, 4 \mathrm{H}) ; 1.56$ (quint, $2 \mathrm{H}, J=6.4 \mathrm{~Hz}) ;{ }^{13} \mathrm{C}$ $\operatorname{NMR}\left(\mathrm{CDCl}_{3}\right) \delta 157.0(2 \mathrm{C}) ; 137.1 ; 128.8 ; 128.3 ; 66.8 ; 56.0 ; 54.0 ; 52.4 ; 42.5 ; 39.7$; 39.3; 27.5; LRMS $\left(\mathrm{ES}^{+}\right) \quad m / e \quad 448.5 \quad[(\mathrm{M}+\mathrm{HCl}), 100 \%] ; 412 \quad[(\mathrm{M}+\mathrm{H})] ;$ Anal. $\left(\mathrm{C}_{23} \mathrm{H}_{30} \mathrm{~N}_{3} \mathrm{O}_{4} \mathrm{Cl} / \mathrm{H}_{2} \mathrm{O}\right)$ calcd: $\mathrm{C}, 59.29 ; \mathrm{H}, 6.92 ; \mathrm{N}, 9.02$; found: $\mathrm{C}, 59.27 ; \mathrm{H}, 7.26 ; \mathrm{N}$, 9.02 .

Acetic acid 2-[(2-benzyloxycarbonylamino-ethyl)-(3benzyloxycarbonylamino-propyl)-amino]-ethyl ester (18). (223 mg, $16 \%$ ); ${ }^{1} \mathrm{H}$ NMR $\left(\mathrm{CDCl}_{3}\right) \delta 7.28($ br s, 10H); $5.68(\mathrm{br}, \mathrm{NH}) ; 5.52(\mathrm{br}, \mathrm{NH}) ; 5.04(\mathrm{~s}, 2 \mathrm{H}) ; 5.02(\mathrm{~s}, 2 \mathrm{H}) ;$ $4.03(\mathrm{t}, 2 \mathrm{H}, J=5.6 \mathrm{~Hz}) ; 3.25-3.05(\mathrm{~m}, 4 \mathrm{H}) ; 2.60(\mathrm{t}, 2 \mathrm{H}, J=5.6 \mathrm{~Hz}) ; 2.55-2.35(\mathrm{~m}, 4 \mathrm{H})$; $1.90(\mathrm{~s}, 3 \mathrm{H}) ; 1.55$ (quint, $2 \mathrm{H}) ;{ }^{13} \mathrm{C} \mathrm{NMR}\left(\mathrm{CDCl}_{3}\right) \delta 171.5 ; 157.0 ; 156.9 ; 137.1 ; 128.9$; $128.5 ; 128.4 ; 66.95 ; 66.87 ; 62.4 ; 54.0 ; 52.7 ; 43.5 ; 39.9 ; 39.2 ; 27.3 ; 21.2 ;$ LRMS $\left(E S^{+}\right)$ $m / e 472[(\mathrm{M}+\mathrm{H}), 100 \%]$. Anal. $\left(\mathrm{C}_{25} \mathrm{H}_{33} \mathrm{~N}_{3} \mathrm{O}_{6}\right) \mathrm{C}, \mathrm{H}, \mathrm{N}$.

\section{$\{3-[(2-B e n z y l o x y c a r b o n y l a m i n o-e t h y l)-(2-h y d r o x y-e t h y l)-a m i n o]-p r o p y l\}-$}

carbamic acid benzyl ester (20). A solution of bromoethanol $(0.03 \mathrm{~mL}, 0.42 \mathrm{mmol})$ in $\mathrm{CH}_{3} \mathrm{CN}(1 \mathrm{~mL})$ was added to a solution of $\mathbf{5 d}(208 \mathrm{mg}, 0.54 \mathrm{mmol})$ in $\mathrm{CH}_{3} \mathrm{CN}(4 \mathrm{~mL})$. The reaction mixture was refluxed $12 \mathrm{~h}$ and the solvent was removed by reduce pressure. The crude product was purified by chromatography with EtOAc/MeOH (80:20) and the resulting compound dissolved in a little $\mathrm{CH}_{2} \mathrm{Cl}_{2}$ was filtered on a path of Celite affording the pure product $20(124 \mathrm{mg}, 69 \%) .{ }^{1} \mathrm{H} \mathrm{NMR}\left(300 \mathrm{MHz}, \mathrm{CDCl}_{3}\right) \delta$ 7.22 (br s, 10H); 5.63 (br, 1H); $5.46(\mathrm{br}, 1 \mathrm{H}) ; 4.97$ (s, 4H); 3.44 (t, 2H, $J=5 \mathrm{~Hz}) ; 3.1$ (m, 5H); 2.5-2.3 (m, 6H); $1.49(\mathrm{~m}, 2 \mathrm{H}) ;{ }^{13} \mathrm{C} \mathrm{NMR}\left(75 \mathrm{MHz}, \mathrm{CDCl}_{3}\right) \delta$ 156.76; 156.57; $136.5 ; 128.3 ; 127.9 ; 66.4 ; 59.1 ; 55.8 ; 53.7 ; 51.3 ; 38.9 ; 38.6 ; 27.0 ;$ IR (neat) $v 3500-$ 3300 (br); 2905; 1680; 1515; 1235; 715; $675 \mathrm{~cm}^{-1}$; LRMS $\left(\mathrm{ES}^{+}\right) \mathrm{m} / z 430$ [(M+H)], 542 [(M+Na), 100\%]; Anal. $\left(\mathrm{C}_{23} \mathrm{H}_{31} \mathrm{~N}_{3} \mathrm{O}_{5} / 1 \mathrm{H}_{2} \mathrm{O}\right)$ calcd: $\mathrm{C}, 61.73 ; \mathrm{H}, 7.43 ; \mathrm{N}, 9.39$; found: C, 61.83; H, 6.98; N, 8.82. 
benzyl ester (25). To a solution of amine $\mathbf{5 d}$ (1.06 g, $2.7 \mathrm{mmol})$ and formaldehyde (37 \% in $\left.\mathrm{H}_{2} \mathrm{O}, 1.5 \mathrm{~mL}, 13.5 \mathrm{mmol}\right)$ in $\mathrm{CH}_{3} \mathrm{CN}$ was added $\mathrm{NaBH}_{3} \mathrm{CN}$ (226 mg, $3.6 \mathrm{mmol}$ ). After $10 \mathrm{~min}$, few drops of $\mathrm{AcOH}$ were added to the cloudy solution to adjust the $\mathrm{pH}$ to 6-7. The reaction was stirred $17 \mathrm{~h}$ at room temperature and the solvent was removed by reduce pressure. The crude residue was treated with water and $1 \mathrm{M} \mathrm{NaOH}$ was added to adjust the $\mathrm{pH}$ to $10-11$. The aqueous phase was extracted 3 times with $\mathrm{CH}_{2} \mathrm{Cl}_{2}$ and the organic extracts were dried $\left(\mathrm{Na}_{2} \mathrm{SO}_{4}\right)$ and concentrated by reduce pressure. The crude oil was chromatographed (40M cartridge) with $\mathrm{CH}_{2} \mathrm{Cl}_{2} / \mathrm{MeOH}$ (98:2). The sixmembered heterocycle 26 was eluted first followed by 25. Compound 25: ${ }^{1} \mathrm{H}$ NMR $\left(300 \mathrm{MHz}, \mathrm{CDCl}_{3}\right) \delta 7.25(\mathrm{~m}, 10 \mathrm{H}) ; 5.3(\mathrm{br}, 1 \mathrm{H}, \mathrm{NH}) ; 5.04(\mathrm{~s}, 2 \mathrm{H}) ; 4.99(\mathrm{~s}, 2 \mathrm{H}) ; 3.94(\mathrm{~s}$, $1 \mathrm{H}) ; 3.89(\mathrm{~s}, 1 \mathrm{H}) ; 3.37(\mathrm{td}, 2 \mathrm{H}, J=8.9$ and $9.3 \mathrm{~Hz}) ; 3.17(\mathrm{td}, 2 \mathrm{H}, J=9.0$ and $9.6 \mathrm{~Hz})$; $2.70(\mathrm{~m}, 2 \mathrm{H}) ; 2.43($ br t, $2 \mathrm{H}, J=9 \mathrm{~Hz}) ; 1.58$ (quint, $2 \mathrm{H}, J=9.7 \mathrm{~Hz}$ ); ${ }^{13} \mathrm{C} \mathrm{NMR}$ $\left(300 \mathrm{MHz}, \mathrm{CDCl}_{3}\right) \delta 157.0 ; 154.4 ; 137.2 ; 129.0 ; 128.6 ; 68.8 ; 68.5 ; 67.4 ; 67.1 ; 53.4$; 52.6; 52.2; 44.9; 44.7; 43.6; 40.2; 28.8; LRMS (ES $\left.{ }^{+}\right)$m/z 398 [(M+H), $100 \%$ \%.

\section{3-(2-Benzyloxycarbonylamino-ethyl)-tetrahydro-pyrimidine-1-carboxylic}

acid benzyl ester (26). ${ }^{1} \mathrm{H} \mathrm{NMR}\left(300 \mathrm{MHz}, \mathrm{CDCl}_{3}\right) \delta 7.3$ (br s, 10H, aro); 5.5 (br, $1 \mathrm{H}$, $\mathrm{NH}) ; 5.1\left[\mathrm{~s}, 2 \mathrm{H}, \mathrm{Ph} \underline{\mathrm{CH}_{2}} \mathrm{OC}(\mathrm{O}) \mathrm{NH}\right] ; 5.06\left[\mathrm{~s}, 2 \mathrm{H}, \mathrm{Ph} \underline{\mathrm{CH}}_{2} \mathrm{OC}(\mathrm{O}) \mathrm{N}\right] ; 4.12\left(\mathrm{~s}, 2 \mathrm{H}, \mathrm{NCH}_{2} \mathrm{~N}\right)$; 3.48 (br t, $2 \mathrm{H}, J=8.2 \mathrm{~Hz}, \mathrm{CbzN \underline {CH } _ { 2 }}$ ); 3.22 (br m, $2 \mathrm{H}, \underline{\mathrm{CH}_{2}} \mathrm{NHCbz}$ ); 2.67 (br t, $2 \mathrm{H}$, $\left.\mathrm{NCH}_{2} \mathrm{CH}_{2}\right) ; 2.49\left(\mathrm{~m}, 2 \mathrm{H}, \underline{\mathrm{NCH}}{ }_{2} \mathrm{CH}_{2} \mathrm{NHCbz}\right) ; 1.53\left(\mathrm{~m}, 2 \mathrm{H}, \mathrm{CH}_{2} \underline{\mathrm{CH}}_{2} \mathrm{CH}_{2}\right) ;{ }^{13} \mathrm{C} \mathrm{NMR}(75$ $\left.\mathrm{MHz}, \mathrm{CDCl}_{3}\right) \delta 156.7[\mathrm{~s}, \mathrm{C}(=\mathrm{O}) \mathrm{NH}] ; 155.28[\mathrm{~s}, C(=\mathrm{O}) \mathrm{N}] ; 136.94(\mathrm{~s}$, aro $) ; 136.86(\mathrm{~s}$, aro); 128.7 (d, aro); 128.3 (d, aro); 128.1 (d, aro); 67.4 [t, $\mathrm{PhCH} 2 \mathrm{OC}(\mathrm{O}) \mathrm{NH}] ; 66.7$ [t, $\left.\mathrm{Ph} \underline{C H}_{2} \mathrm{OC}(\mathrm{O}) \mathrm{N}\right] ; 65.1\left(\mathrm{t}, \mathrm{N} \underline{\mathrm{CH}}_{2} \mathrm{~N}\right) ; 51.9$ (t, $\left.\mathrm{N} \underline{\mathrm{CH}}_{2} \mathrm{CH}_{2}\right) ; 44.1$ (t, $\left.\mathrm{CbzNCH} \underline{H}_{2}\right) ; 38.3$ (t, $\left.\underline{\mathrm{CH}}_{2} \mathrm{NHCbz}\right) ; 22.5$ (t, $\left.\mathrm{CH}_{2} \underline{\mathrm{CH}}_{2} \mathrm{CH}_{2}\right)$; LRMS (ES $\left.{ }^{+}\right) \mathrm{m} / z 398$ [(M+H), $100 \%$ ].

4,4'-Bis $\left[N^{3}\right.$-(2,2-diethoxyethyl)guanidino]diphenylmethane (31c). A $1 \mathrm{M}$ ether 
solution of 2,2-diethoxy-ethyl-carbodiimide $(11.1 \mathrm{~mL}, 11.1 \mathrm{mmol})$ was added to a solution of 4,4'-diaminodiphenylmethane (1.05 g, $5.3 \mathrm{mmol})$ in dry EtOH under $\mathrm{N}_{2}$. Methanesulfonic acid $(0.69 \mathrm{~mL}, 10.6 \mathrm{mmol})$ was added drop wise to the clear reaction mixture and a white precipitate formed immediately. The reaction was refluxed $44 \mathrm{~h}$ and then poured into $0.5 \mathrm{M}$ aqueous $\mathrm{NaOH}$ solution. The aqueous phase was extracted $\left(3 \times \mathrm{CH}_{2} \mathrm{Cl}_{2}\right)$. Organic extracts were dried $\left(\mathrm{Na}_{2} \mathrm{SO}_{4}\right)$ and concentrated by reduce pressure. The guanidine 31c was crystallised with $\mathrm{CH}_{2} \mathrm{Cl}_{2}$ and washed with $\mathrm{Et}_{2} \mathrm{O}$. Some more compound was obtained by precipitation of the mother liquor with $\mathrm{Et}_{2} \mathrm{O}$. Colorless solid (926 mg, $34 \%$ ); mp 188-190 ${ }^{\circ} \mathrm{C} ;{ }^{1} \mathrm{H} \mathrm{NMR}\left(\mathrm{CDCl}_{3} / \mathrm{CD}_{3} \mathrm{OD}\right) \delta 7.0$ (d, 4H, $J=7.5 \mathrm{~Hz}$ ); $6.73(\mathrm{~d}, 4 \mathrm{H}, J=7.5 \mathrm{~Hz}) ; 4.44(\mathrm{t}, 2 \mathrm{H}, J=4.8 \mathrm{~Hz}) ; 3.75(\mathrm{~s}, 2 \mathrm{H}) ; 3.8-3.4(\mathrm{~m}, 8 \mathrm{H}) ; 3.19(\mathrm{~d}$, $4 \mathrm{H}, \quad J=4.8 \mathrm{~Hz}) ; 1.12(\mathrm{t}, \quad 12 \mathrm{H}, \quad J=7 \mathrm{~Hz}) ;{ }^{13} \mathrm{C} \quad\left(\mathrm{CDCl}_{3} / \mathrm{CD}_{3} \mathrm{OD}\right)$ $\delta 154.5 ; 146.6 ; 136.1 ; 130.2 ; 124.2 ; 102.6 ; 63.8 ; 45.1 ; 41.2 ; 15.6$; LRMS (EI) $\mathrm{m} / z 514$ $\left[\left(\mathrm{M}^{+}\right), 70 \%\right], 485[(\mathrm{M}-29), 100 \%]$; Anal. $\left(\mathrm{C}_{27} \mathrm{H}_{42} \mathrm{~N}_{6} \mathrm{O}_{4}\right) \mathrm{C}, \mathrm{H}, \mathrm{N}$.

4,4'-Bis $\left[N^{3}\right.$-(2,2-diethoxyethyl)guanidino]diphenylamine $\quad$ (32c). Same procedure as 31c starting from 4,4'-diaminodiphenylamine (421 mg, $2.1 \mathrm{mmol}$ ), 2,2diethoxy-ethyl-carbodiimide $(4.6 \mathrm{~mL}, 4.6 \mathrm{mmol})$ and methanesulfonic acid $(0.27 \mathrm{~mL}$, $4.2 \mathrm{mmol}$ ). The crude product dissolved in $\mathrm{EtOH}$ was treated with $\mathrm{Et}_{2} \mathrm{O}$. The solid precipitate was filtered off and the mother liquor was concentrated by reduce pressure. The residue was dissolved in $\mathrm{MeOH}$ and 32c was isolated by $\mathrm{Et}_{2} \mathrm{O}$ mediated precipitation (707 mg, $65 \%$ ); Methanesulfonate salt of 32c: purple solid; IR (KBr) $v$ $1625 ; 1600 ; 1480 ; 1175 ; 1160 ; 1025 ; 1015 ; 750 ; 737 \mathrm{~cm}^{-1} ;{ }^{1} \mathrm{H}$ NMR $\left(\mathrm{D}_{2} \mathrm{O}\right) \delta 7.11(\mathrm{~s}$, $8 \mathrm{H}) ; 4.65(\mathrm{~m}, 2 \mathrm{H}) ; 3.8-3.4(\mathrm{~m}, 8 \mathrm{H}) ; 3.33(\mathrm{~m}, 4 \mathrm{H}) ; 1.11(\mathrm{t}, 12 \mathrm{H}, J=7.1 \mathrm{~Hz}) ;{ }^{13} \mathrm{C} \mathrm{NMR}$ $\left(\mathrm{D}_{2} \mathrm{O}\right) \delta 156.7 ; 143.1 ; 127.8 ; 126.9 ; 118.9 ; 101.3 ; 65.0 ; 44.9 ; 15.2 ;$ LRMS $\left(\mathrm{ES}^{+}\right) \mathrm{m} / \mathrm{e}$ $516\left[(\mathrm{M}+\mathrm{H}), 100 \%\right.$ \%. Anal. $\left(\mathrm{C}_{28} \mathrm{H}_{49} \mathrm{~N}_{7} \mathrm{O}_{10} \mathrm{~S}_{2} / 2 \mathrm{H}_{2} \mathrm{O}\right)$ calcd: $\mathrm{C}, 45.21 ; \mathrm{H}, 7.18 ; \mathrm{N}, 13.18$; S, 8.62; found: C, 44.80; H, 7.02; N, 12.70; S, 9.08. 
4,4'-Bis(2-imidazolylamino)diphenylamine (35). In a flask cooled to $0{ }^{\circ} \mathrm{C}$, was dissolved the guanidine 32c $(350 \mathrm{mg}, 0.68 \mathrm{mmol})$ in $6 \mathrm{M} \mathrm{HCl}(5 \mathrm{~mL})$. After stirring $3 \mathrm{~h}$ at room temperature, $10 \% \mathrm{NaOH}$ was added until a precipitate formed $(\mathrm{pH}>11)$. The reaction mixture was stirred $75 \mathrm{~min}$ and was poured into a $1 \mathrm{M} \mathrm{NaOH}$ solution. The aqueous phase was extracted with $\mathrm{CH}_{2} \mathrm{Cl}_{2}$. The crude product was collected by filtration of the aqueous phase. The crude solid was dissolved in boiling water $(10 \mathrm{~mL})$ and the flask was allowed to stand overnight at room temperature. The product was collected by filtration, washed several times with $\mathrm{H}_{2} \mathrm{O}$ and dried in vacuo at $50{ }^{\circ} \mathrm{C}$ affording the free base of 35 as a purple solid $(82 \mathrm{mg}$ ). The hydrochloride salt was prepared in the following manner: to 35 dissolved in $\mathrm{H}_{2} \mathrm{O}$ was added $3 \mathrm{~N} \mathrm{HCl}$ until $\mathrm{pH} 2$ was reached. The compound was lyophilised, dissolved in $\mathrm{MeOH}$ and purified by $\mathrm{Et}_{2} \mathrm{O}$ mediated precipitation. Purple solid (51 mg, $19 \%$ ); mp > 200 oC (dec.); IR (KBr) v 1650; 1590; 1500; 1310; 815; $670 \mathrm{~cm}^{-1} ;{ }^{1} \mathrm{H}$ NMR $\left(\mathrm{D}_{2} \mathrm{O}\right) \delta 7.15$ (br s, $\left.8 \mathrm{H}\right) ; 6.76$ (br s, $\left.4 \mathrm{H}\right) ;{ }^{13} \mathrm{C} \mathrm{NMR}$ $\left(\mathrm{D}_{2} \mathrm{O}\right) \delta 145.9(\mathrm{~s}) ; 142.5(\mathrm{~s}) ; 130.2(\mathrm{~s}) ; 125.4(\mathrm{~d}) ; 119.8$ (d); $114.0(\mathrm{~d}) ;$ LRMS $_{\left(\mathrm{ES}^{+}\right)}$m/e $332[(\mathrm{M}+\mathrm{H}), 100 \%] ; 166.6[(\mathrm{M}+2 \mathrm{H})]$; Anal. $\left(\mathrm{C}_{18} \mathrm{H}_{20} \mathrm{Cl}_{3} \mathrm{~N}_{7}\right)$ calcd: $\mathrm{C}, 49.05 ; \mathrm{H}, 4.57 ; \mathrm{N}$, 22.25; found: C, 49.71; H, 4.45; N, 21.66.

Bis-(4-bromomethyl-phenyl)-methanone (36). A solution of 4,4'dimethylbenzophenone $(1 \mathrm{~g}, 4.8 \mathrm{mmol})$, NBS $(1.71 \mathrm{~g}, 9.6 \mathrm{mmol})$ and four drops of $t$ $\mathrm{BuOOH}$ in $\mathrm{CCl}_{4}(15 \mathrm{~mL})$ was heated at reflux for $18 \mathrm{~h}$ under argon atmosphere. The insoluble succinimide was filterered off and the solvent was removed by reduce pressure. The pure product was obtained by crystallisation from $\mathrm{CH}_{2} \mathrm{Cl}_{2}$ as colorless needles (387 mg, $22 \%)$; mp 135-137 ${ }^{\circ} \mathrm{C}$; IR (KBr) $v 1630,1585,1390,1255,1155$, 905, $665 \mathrm{~cm}^{-1} ;{ }^{1} \mathrm{H}$ NMR $\left(\mathrm{CDCl}_{3}\right) \delta 7.78(\mathrm{~d}, 4 \mathrm{H}, J=8.4 \mathrm{~Hz}) ; 7.51(\mathrm{~d}, 4 \mathrm{H}, J=8.4 \mathrm{~Hz})$; $4.57(\mathrm{~s}, 4 \mathrm{H}) ;{ }^{13} \mathrm{C} \mathrm{NMR}\left(\mathrm{CDCl}_{3}\right) \delta 195.8 ; 142.9,137.8,131.1,129.6,32.9$; Anal. $\left(\mathrm{C}_{15} \mathrm{H}_{12} \mathrm{Br}_{2} \mathrm{O} / 0.5 \mathrm{H}_{2} \mathrm{O}\right)$ calcd: $\mathrm{C}, 47.78 ; \mathrm{H}, 3.47$; found: $\mathrm{C}, 47.87 ; \mathrm{H}, 3.08$. 
Tri-n-pentylphosphine. To a suspension of magnesium (1.96 g) in dry THF (50 $\mathrm{mL})$ under argon, was added a solution of 1-bromopentane $(10 \mathrm{~mL}, 80.7 \mathrm{mmol})$ in THF $(20 \mathrm{~mL})$. The resulting reaction mixture was heated at reflux for $20 \mathrm{~min}$. Then, the reaction was cooled to $-78{ }^{\circ} \mathrm{C}$ and a solution of phosphorous trichloride $(1.74 \mathrm{~mL}, 20$ mmol) in THF $(10 \mathrm{~mL})$ was added drop wise. The reaction was stirred $30 \mathrm{~min}$ at $-78^{\circ} \mathrm{C}$ and the cold bath was removed. The reaction was allowed to warm up to room temperature and was then heated at reflux for $30 \mathrm{~min}$. The reaction was quenched with saturated $\mathrm{NH}_{4} \mathrm{Br}$ solution $(20 \mathrm{~mL})$. The precipitate was filtered off under argon atmosphere and the crude product was distilled under vacuum, affording the tri- $n$ pentylphosphine as a colorless oil (1.305 g, $27 \%)$. The product was conserved under argon in the fridge. $\mathrm{Bp}(3 \mathrm{~mm} \mathrm{Hg}) 115-125{ }^{\circ} \mathrm{C} ;{ }^{1} \mathrm{H}$ NMR $\left(\mathrm{CDCl}_{3}\right) \delta 1.61(\mathrm{~m}, 6 \mathrm{H}) ; 1.36$ $(\mathrm{m}, 18 \mathrm{H}) ; 0.88(\mathrm{~m}, 9 \mathrm{H}) ;{ }^{13} \mathrm{C}$ NMR $\left(\mathrm{D}_{2} \mathrm{O}\right) \delta 33.9\left(\mathrm{~d}, J^{31} \mathrm{P}_{-}{ }^{13} \mathrm{C}=13.7 \mathrm{~Hz}\right), 29.1,27.8$, 22.8, 22.0, 14.5; ${ }^{31} \mathrm{P} \mathrm{NMR}\left(\mathrm{CDCl}_{3}\right) \delta 50.23$.

4,4'-Bis(tri-n-pentylphosphonium)benzophenone bromide (37). A solution of 36 (344 mg, $0.93 \mathrm{mmol})$ and tri- $n$-pentylphosphine $(1.02 \mathrm{~g}, 4.2 \mathrm{mmol})$ in dry toluene $(10 \mathrm{~mL})$ was heated at reflux for $24 \mathrm{~h}$. The precipitate that had formed while cooling the reaction mixture was triturated with a spatula until a solid formed. The solid was collected by filtration, rinsed with dry toluene and dried in vacuo at $70{ }^{\circ} \mathrm{C}$. Colorless hygroscopic solid (748 mg, $94 \%$ ); Spectroscopic data are in agreement with the literature. ${ }^{37}$ LRMS $\left(\mathrm{FAB}^{+}\right)$m/e $695.5\left[\left(\mathrm{M}^{+}\right) ; 100 \%\right]$; Anal. $\left(\mathrm{C}_{45} \mathrm{H}_{78} \mathrm{OP}_{2} \mathrm{Br}_{2}\right) \mathrm{C}, \mathrm{H}$.

1,4-Bis-(4-nitro-phenyl)-piperazine (38). ${ }^{54} \mathrm{~A}$ solution of 1-(4-nitro-phenyl)piperazine $(2.58 \mathrm{~g}, 12.5 \mathrm{mmol})$ and 1-fluoro-4-nitrobenzene $(599 \mathrm{mg}, 4.16 \mathrm{mmol})$ in DMSO $(15 \mathrm{~mL})$ was heated $60 \mathrm{~h}$ at $100{ }^{\circ} \mathrm{C}$. The cool reaction was poured into water $(50$ $\mathrm{mL}$ ). The precipitate was collected by filtration and rinsed with a small quantity of water. The product was first crystallised with $\mathrm{PhMe} / \mathrm{EtOH}$ and rinsed with cold toluene 
and cold EtOH respectively. The pure compound was obtained as a red solid by crystallisation with $\mathrm{CH}_{3} \mathrm{CN}(1 \mathrm{~g}, 73 \%)$. Mp 265-266 ${ }^{\circ} \mathrm{C}$ [Lit. ${ }^{54} 261{ }^{\circ} \mathrm{C}, \mathrm{PhNO}_{2}$ ]; ${ }^{1} \mathrm{H}$ NMR $\left(D_{M S O}-d_{6}\right) \delta 8.1(\mathrm{~d}, 4 \mathrm{H}, J=9 \mathrm{~Hz}) ; 7.0(\mathrm{~d}, 4 \mathrm{H}, J=9 \mathrm{~Hz}) ; 3.71(\mathrm{~s}, 8 \mathrm{H}) ;{ }^{13} \mathrm{C} \mathrm{NMR}$ $($ DMSO-d 6$) \delta 153.9 ; 136.8 ; 125.6 ; 111.9 ; 45.1$. Anal. $\left(\mathrm{C}_{16} \mathrm{H}_{16} \mathrm{~N}_{4} \mathrm{O}_{4} / 0.8 \mathrm{H}_{2} \mathrm{O}\right)$ calcd: $\mathrm{C}$, 56.10; H, 5.18; N, 16.36; found: C, 56.12; H, 5.35; N, 16.24 .

1,4-Bis-(4-amino-phenyl)-piperazine (39). ${ }^{42}$ The nitro compound 38 ((705 mg, $2.1 \mathrm{mmol})$ was dissolved in $\mathrm{HCl}$ saturated methanolic solution $(70 \mathrm{~mL})$. The solution was hydrogenated $\left(40 \mathrm{Psi}_{2}\right)$ in the presence of $10 \% \mathrm{Pd}-\mathrm{C}(165 \mathrm{mg})$ for $14 \mathrm{~h}$ at room temperature. The catalyst was filtered off and the solvent was removed by reduce pressure affording the crude hydrochloride of 39. Recrystallisation with EtOH afforded the pure $\mathrm{HCl}$ salt of $39(300 \mathrm{mg}, 41 \%) ; \mathrm{mp}>350{ }^{\circ} \mathrm{C} ;{ }^{1} \mathrm{H}$ NMR $\left(\mathrm{D}_{2} \mathrm{O}\right) \delta 7.24(\mathrm{~s}, 8 \mathrm{H})$; $3.49(\mathrm{~s}, 8 \mathrm{H})$; LRMS $\left(\mathrm{ES}^{+}\right) \mathrm{m} / z 269[(\mathrm{M}+\mathrm{H}), 100 \%], 135[(\mathrm{M}+2 \mathrm{H})]$. Anal. $\left(\mathrm{C}_{16} \mathrm{H}_{24} \mathrm{Cl}_{4} \mathrm{~N}_{4}\right.$ / $1.7 \mathrm{H}_{2} \mathrm{O}$ ) calcd: $\mathrm{C}, 43.40 ; \mathrm{H}, 6.24 ; \mathrm{N}, 12.65$; found: $\mathrm{C}, 43.08 ; 5.49 ; \mathrm{N}, 12.83$.

\section{1,4-Bis-[4-( $N^{2}, N^{3}$-di(tert-butyloxycarbonyl)guanidino)-phenyl]-piperazine}

(40a). To a solution of 39 (54 mg, $0.2 \mathrm{mmol}), N, N^{\prime}$-di(tert-butoxycarbonyl)thiourea (122 mg, $0.44 \mathrm{mmol})$, and $\mathrm{Et}_{3} \mathrm{~N}(0.14 \mathrm{~mL}, 1 \mathrm{mmol})$ in $\mathrm{DMF}(2 \mathrm{~mL})$ at $0{ }^{\circ} \mathrm{C}$ under $\mathrm{N}_{2}$ was added $\mathrm{HgCl}_{2}(119 \mathrm{mg}, 0.44 \mathrm{mmol})$ at once. A precipitate formed immediately. The resulting dark reaction mixture was stirred $30 \mathrm{~min}$ at $0{ }^{\circ} \mathrm{C}$ and 2.5 days at room temperature. The reaction was diluted with $\mathrm{CH}_{2} \mathrm{Cl}_{2}$ and filtered through a path of Celite. The filter cake was rinsed with $\mathrm{CH}_{2} \mathrm{Cl}_{2}$. the organic phase was washed with brine, dried $\left(\mathrm{MgSO}_{4}\right)$ and concentrated. Non-mobile impurities were removed by a short flash chromatography on silica with Hexane/EtOAc (75:25). The pure product was obtained by crystallisation from hexane. Yellowish solid (110 mg, $73 \%) ; \mathrm{mp}>300{ }^{\circ} \mathrm{C}$ dec.; ${ }^{1} \mathrm{H}$ $\operatorname{NMR}\left(\mathrm{CDCl}_{3}\right) \delta 11.64(\mathrm{br}, 2 \mathrm{H}) ; 10.17(\mathrm{br}, 2 \mathrm{H}) ; 7.47(\mathrm{~d}, 4 \mathrm{H}, J=8.9 \mathrm{~Hz}) ; 6.92(\mathrm{~d}, 4 \mathrm{H}, J$ $=8.9 \mathrm{~Hz}) ; 3.27(\mathrm{~s}, 8 \mathrm{H}) ; 1.5($ br s, $36 \mathrm{H}) ;{ }^{13} \mathrm{C} \mathrm{NMR}\left(\mathrm{CDCl}_{3}\right) \delta 164.2 ; 154.1 ; 153.9 ; 149.2$; 
$130.0 ; 124.1 ; 117.4 ; 84.0 ; 79.9 ; 50.3 ; 28.7 ;$ LRMS $\left(\mathrm{ES}^{+}\right) \mathrm{m} / z 753[(\mathrm{M}+\mathrm{H})]$; Anal. $\left(\mathrm{C}_{38} \mathrm{H}_{56} \mathrm{~N}_{8} \mathrm{O}_{8} / 0.7 \mathrm{C}_{6} \mathrm{H}_{14}\right)$ calcd: C, 62.37; H, 8.16; N, 13.79; found: C, 62.23; H, 8.80; N, 14.11 .

1,4-Bis-(4-guanidino-phenyl)-piperazine (40b). TFA $(2 \mathrm{~mL})$ was added to a stirred solution of $40 \mathrm{a}(37 \mathrm{mg}, 0.049 \mathrm{mmol})$ in $\mathrm{CH}_{2} \mathrm{Cl}_{2}(3 \mathrm{~mL})$. After 2 days, the volatiles were removed by reduce pressure and the product was precipitated by addition of $\mathrm{Et}_{2} \mathrm{O}$. The compound was dried in vacuo affording $\mathbf{4 0 b}$ as a greenish hygroscopic solid (25 mg, $88 \%$ ). Trifluoroacetic salt of 40b. ${ }^{1} \mathrm{H}$ NMR $\left(\mathrm{D}_{2} \mathrm{O}\right) \delta 7.19(\mathrm{~m}, 8 \mathrm{H}) ; 3.36$ $(\mathrm{s}, 8 \mathrm{H}) ;{ }^{13} \mathrm{C}$ NMR $\left(\mathrm{D}_{2} \mathrm{O}\right) \delta 156.2 ; 148.4 ; 128.2 ; 127.1 ; 118.7 ; 49.4 ;$ LRMS $\left(\mathrm{ES}^{+}\right) \mathrm{m} / \mathrm{z}$ $353[(\mathrm{M}+\mathrm{H})], 177[(\mathrm{M}+2 \mathrm{H}), 100 \%]$. Anal. $\left(\mathrm{C}_{24} \mathrm{H}_{27} \mathrm{~F}_{9} \mathrm{~N}_{8} \mathrm{O}_{6}\right)$ calcd: $\mathrm{C}, 41.51 ; \mathrm{H}, 3.92 ; \mathrm{N}$, 16.13; found: C, 41.52; H, 4.33; N, 17.04 .

Di(tert-butyl) ～2-(4-[4-(4-[1,3-di(tert-butyloxycarbonyl)tetrahydro-1H-2imidazolyliden]aminophenyl)piperazino]phenylimino)-1,3-

imidazolidinedicarboxylate (41a). Same procedure as 40a starting from the $\mathrm{HCl}$ salt of 39 (111 mg, $0.27 \mathrm{mmol}), \mathrm{Et}_{3} \mathrm{~N}(0.37 \mathrm{~mL}, 2.7 \mathrm{mmol}), \mathrm{HgCl}_{2}(160 \mathrm{mg}, 0.59 \mathrm{mmol})$ and using $N, N^{\prime}$-di(tert-butoxycarbonyl)imidazoline-2-thione (178 $\left.\mathrm{mg}, 0.59 \mathrm{mmol}\right)$ as reagent for the introduction of the imidazoline nucleus. Flash chromatography with Hexane/EtOAc (50:50) afforded the product as a colorless solid (143 mg, $66 \%) .{ }^{1} \mathrm{H}$ $\mathrm{NMR}\left(\mathrm{CDCl}_{3}\right) \delta 6.9(\mathrm{~m}, 8 \mathrm{H}) ; 3.79(\mathrm{~s}, 8 \mathrm{H}) ; 3.20(\mathrm{~s}, 8 \mathrm{H}) ; 1.31(\mathrm{~s}, 36 \mathrm{H}) ;{ }^{13} \mathrm{C} \mathrm{NMR}$ $\left(50 \mathrm{MHz}, \mathrm{CDCl}_{3}\right) \delta 150.3(\mathrm{~s}) ; 147.2(\mathrm{~s}) ; 141.5(\mathrm{~s}) ; 138.5$ (s); 122.1 (d); 117.3 (d); 82.4 (s); $50.4(\mathrm{t}) ; 42.9$ (t); 27.7 (q); Anal. $\left(\mathrm{C}_{42} \mathrm{H}_{60} \mathrm{~N}_{8} \mathrm{O}_{8}\right) \mathrm{C}, \mathrm{H}, \mathrm{N}$.

1,4-bis[4-(4,5-dihydro-1H-2-imidazolylamino)phenyl]piperazine (41b). TFA (2 mL) was added to a stirred solution of $41 \mathrm{a}(65 \mathrm{mg}, 0.08 \mathrm{mmol})$ in $\mathrm{CH}_{2} \mathrm{Cl}_{2}(3 \mathrm{~mL})$. After $12 \mathrm{~h}$, the volatiles were removed by reduce pressure and the product dissolved in water was extracted with $\mathrm{CH}_{2} \mathrm{Cl}_{2}$ to remove organic soluble impurities. The water was 
evaporated and the product was dried in vacuo to afford $\mathbf{4 1 b}$ as a greenish hygroscopic solid. ${ }^{1} \mathrm{H}$ NMR $\left(\mathrm{D}_{2} \mathrm{O}\right) \delta$ 7.3-7.0 (br m, 8H); $3.63(\mathrm{~s}, 8 \mathrm{H}) ; 3.59(\mathrm{~s}, 8 \mathrm{H}) ;{ }^{13} \mathrm{C} \mathrm{NMR}$ $\left(\mathrm{CD}_{3} \mathrm{OD}, 75 \mathrm{MHz}\right) \delta 161.1 ; 152.5 ; 128.7 ; 127.4 ; 118.6 ; 50.6 ; 44.5 ;$ LRMS $\left(\mathrm{ES}^{+}\right) \mathrm{m} / \mathrm{z}$ $405[(\mathrm{M}+\mathrm{H})] ; 203.2[(\mathrm{M}+2 \mathrm{H}), 100 \%]$; Anal. $\left(\mathrm{C}_{26} \mathrm{H}_{30} \mathrm{~F}_{6} \mathrm{~N}_{8} \mathrm{O}_{4}\right) \mathrm{C}, \mathrm{H}, \mathrm{N}$.

\section{Biological tests}

In Vitro antitrypanosomal activity against Trypanosoma brucei rhodesiense. Minimum Essential Medium (50 $\mu \mathrm{l})$ supplemented with $25 \mathrm{mM}$ HEPES, 1g/l additional glucose, 1\% MEM non-essential amino acids (100x), $0.2 \mathrm{mM}$ 2-mercaptoethanol, 2mM Na-pyruvate, $0.1 \mathrm{mM}$ hypoxanthine and $15 \%$ heat inactivated horse serum was added to each well of a 96-well microtiter plate. 3-fold serial drug dilutions were prepared in duplicate in the columns covering a range from $90 \mu \mathrm{g} / \mathrm{ml}$ to $0.123 \mu \mathrm{g} / \mathrm{ml}$. Then $10^{4}$ bloodstream forms of $T$. b. rhodesiense STIB 900 in $50 \mu$ was added to each well and the plate incubated at $37{ }^{\circ} \mathrm{C}$ under a $5 \% \mathrm{CO}_{2}$ atmosphere for $72 \mathrm{~h}$. Alamar Blue $(10 \mu \mathrm{l})$ was then added to each well and incubation continued for a further $2-4 \mathrm{~h}$. Then the plates were read with a Spectramax Gemini XS microplate fluorometer (Molecular Devices Cooperation, Sunnyvale, CA, USA) using an excitation wave length of $536 \mathrm{~nm}$ and an emission wave length of $588 \mathrm{~nm}$. Data are analysed using the microplate reader software Softmax Pro (Molecular Devices Cooperation, Sunnyvale, CA, USA).

In vitro cytotoxicity with L-6 cells. Assays were performed in 96-well microtiter plates, each well containing $100 \mu \mathrm{l}$ of RPMI 1640 medium supplemented with $1 \%$ Lglutamine $(200 \mathrm{mM})$ and $10 \%$ fetal bovine serum, and $4 \times 10^{4}$ L-6 cells (rat skeletal myoblasts) with or without a serial drug dilution columns covering a range from 90 $\mu \mathrm{g} / \mathrm{ml}$ to $0.123 \mu \mathrm{g} / \mathrm{ml}$. Each compound was tested in duplicate. After 72hours of 
incubation the plates were inspected under an inverted microscope to assure growth of the controls and sterile conditions. $10 \mu \mathrm{l}$ of Alamar Blue was then added to each well and the plates incubated for another 2 hours. Then the plates were read with a Spectramax Gemini XS microplate fluorometer (Molecular Devices Cooperation, Sunnyvale, CA, USA) using an excitation wave length of $536 \mathrm{~nm}$ and an emission wave length of $588 \mathrm{~nm}$. Data were analysed using the microplate reader software Softmax Pro (Molecular Devices Cooperation, Sunnyvale, CA, USA).

Acknowledgment. We gratefully acknowledge the European Commission (Marie Curie Research Training grant, category 20), the Spanish MECD (SB2001-0174) and the UNDP/World Bank/WHO Special Programme for Research and Training in Tropical Diseases (TDR). The excellent technical assistance of Elke Gobright at the Swiss Tropical Institute is highly acknowledged. 


\section{References}

(1) http://www.who.int/tdr/diseases/tryp/diseaseinfo.htm

(2) Pepin, J.; Milord, F.; Khonde, A.; Niyonsenga, T.; Loko, L.; Mpia, B. Gambiense trypanosomiasis: frequency of, and risk factors for, failure of melarsoprol therapy. Trans $R$ Soc Trop Med Hyg 1994, 88, 447-452.

(3) Barrett, M. P. The fall and rise of sleeping sickness. Lancet 1999, 353, 11131114.

(4) Barrett, M. P. Problems for the chemotherapy of human African trypanosomiasis. Curr Opin Infect Dis 2000, 13, 647-651.

(5) Jancso, N. Chemotherapeutic action and carbohydrate metabolism. The curative action of guanidine derivatives on trypanosome infections. $Z$ Immunitaetsforsch 1935, $86,1-30$.

(6) King, H.; Lourie, E. M.; Yorke, W. New trypanocidal substances. Lancet 1937, II, 1360-1363.

(7) Lourie, E. M.; Yorke, W. Studies in chemotherapy. XVI. The trypanocidal action of synthalin. Ann Trop Med Parasitol 1937, 31, 435-445.

(8) King, H.; Lourie, E. M.; Yorke, W. Chemotherapy. XIX. Further report on new trypanocidal substances. Ann Trop Med Parasitol 1938, 32, 177-192.

(9) Ashley, J. N.; Barber, H. J.; Ewins, A. J.; Newbery, G.; Self, A. D. H. A chemotherapeutic comparison of the trypanociadal action of some aromatic diamidines. J Chem Soc 1942, 103-116.

(10) Safir, S. R.; Kushner, S.; Brancone, L. M.; Subbarow, Y. Experimental chemotherapy of trypanosomiasis. II. The preparation of compounds related to p-phenylenediguanide. J Org Chem 1948, 13, 924-932. 
(11) Lourie, E. M.; Yorke, W. Studies in chemotherapy. XXI. The trypanocidal action of certain aromatic diamidines. Ann Trop Med Parasitol 1939, 37, 404.

(12) Sands, M.; Kron, M. A.; Brown, R. B. Pentamidine: a review. Rev Infect Dis 1985, $7,625-634$.

(13) Keiser, J.; Stich, A.; Burri, C. New drugs for the treatment of human African trypanosomiasis: research and development. Trends Parasitol 2001, 17, 42-49.

(14) Donkor, I. O.; Assefa, H.; Rattendi, D.; Lane, S.; Vargas, M.; Goldberg, B.; Bacchi, C. Trypanocidal activity of dicationic compounds related to pentamidine. Eur J Med Chem 2001, 36, 531-538.

(15) Donkor, I. O.; Huang, T. L.; Tao, B.; Rattendi, D.; Lane, S.; Vargas, M.; Goldberg, B.; Bacchi, C. Trypanocidal activity of conformationally restricted pentamidine congeners. $J$ Med Chem 2003, 46, 1041-1048.

(16) Muller, S.; Coombs, G. H.; Walter, R. D. Targeting polyamines of parasitic protozoa in chemotherapy. Trends Parasitol 2001, 17, 242-249.

(17) Casero, R. A., Jr.; Woster, P. M. Terminally alkylated polyamine analogues as chemotherapeutic agents. $J$ Med Chem 2001, 44, 1-26.

(18) Edwards, M. L.; Prakash, N. J.; Stemerick, D. M.; Sunkara, S. P.; Bitonti, A. J.; Davis, G. F.; Dumont, J. A.; Bey, P. Polyamine analogues with antitumor activity. J Med Chem 1990, 33, 1369-1375.

(19) Edwards, M. L.; Stemerick, D. M.; Bitonti, A. J.; Dumont, J. A.; McCann, P. P.; Bey, P.; Sjoerdsma, A. Antimalarial polyamine analogues. J Med Chem 1991, $34,569-574$.

(20) Klenke, B.; Stewart, M.; Barrett, M. P.; Brun, R.; Gilbert, I. H. Synthesis and biological evaluation of s-triazine substituted polyamines as potential new antitrypanosomal drugs. J Med Chem 2001, 44, 3440-3452. 
(21) Baillet, S.; Buisine, E.; Horvath, D.; Maes, L.; Bonnet, B.; Sergheraert, C. 2Amino diphenylsulfides as inhibitors of trypanothione reductase: modification of the side chain. Bioorg Med Chem 1996, 4, 891-899.

(22) Bonnet, B.; Soullez, D.; Davioud-Charvet, E.; Landry, V.; Horvath, D.; Sergheraert, C. New spermine and spermidine derivatives as potent inhibitors of Trypanosoma cruzi trypanothione reductase. Bioorg Med Chem 1997, 5, 12491256.

(23) Bonnet, B.; Soullez, D.; Girault, S.; Maes, L.; Landry, V.; Davioud-Charvet, E.; Sergheraert, C. Trypanothione reductase inhibition/trypanocidal activity relationships in a 1,4-bis(3-aminopropyl)piperazine series. Bioorg Med Chem 2000, $8,95-103$.

(24) Trouiller, P.; Olliaro, P. L. Drug development output: what proportion for tropical diseases? Lancet 1999, 354, 164.

(25) Hirst, S. I.; Stapley, L. A. Parasitology: the dawn of a new millennium. Parasitol Today 2000, 16, 1-3.

(26) Dardonville, C.; Goya, P.; Rozas, I.; Alsasua, A.; Martin, M. I.; Borrego, M. J. New aromatic iminoimidazolidine derivatives as alphal-adrenoceptor antagonists: a novel synthetic approach and pharmacological activity. Bioorg Med Chem 2000, 8, 1567-1577.

(27) Dardonville, C.; Rozas, I.; Callado, L. F.; Meana, J. J. I(2)-imidazoline binding site affinity of a structurally different type of ligands. Bioorg Med Chem 2002, $10,1525-1533$.

(28) Dardonville, C.; Rozas, I.; Goya, P.; Giron, R.; Goicoechea, C.; Martin, M. I. Synthesis and analgesic activity of a series of new azaalkane bis- guanidinium 
and bis(2-aminoimidazolinium) compounds. Bioorg Med Chem 2003, 11, 12831291.

(29) Brown, J. G.; Payne, H. A. S. Fungicidal 1,8-diguanidinium salts; Patent GE 2219461, Offen: Germany, 1972.

(30) Mueller, T.; Zipplies, M.; Ammermann, E.; Lorenz, G. Bisguanidines and fungicides containing them; Patent US005242948A, BASF Aktiengesellschaft: Germany, 1993.

(31) Puetzer, B. Guanyl and biguanyl compounds; Patent US2213474; Winthrop Chemical Company: USA, 1940.

(32) Ueda, T. Bis(guanidinopropyl)amine derivatives: Japan, 1963; pp 177.

(33) Murahashi, S.-I.-.; Naota, T.; Nakajima, N. Chemoselective acylation of primary amines in the presence of secondary amines with acyl cyanide. Chem Lett 1987, 879-882.

(34) Borch, R. F.; Bernstein, M. D.; Durst, H. The cyanohydridoborate anion as a selective reducing agent. J Am Chem Soc 1971, 93, 2897-2904.

(35) Katritzky, A. R.; Murugan, R.; Luce, H.; Chen, B. C.; Brey, W. S.; Zerner, M. C. Acyl derivatives of cyclic secondary amines. Part 2. Dynamic ${ }^{1} \mathrm{H}$ and ${ }^{13} \mathrm{C}$ nuclear magnetic resonance studies on bis- and tris-amides: equilibria of synanti interconversion. J Chem Soc Perkin Trans II 1987, 1701-1705.

(36) Munk, S. A.; Harcourt, D. A.; Arasasingham, P. N.; Burke, J. A.; Kharlamb, A. B.; Manlapaz, C. A.; Padillo, E. U.; Roberts, D.; Runde, E.; Williams, L.; Wheeler, L. A.; Garst, M. E. Synthesis and evaluation of 2(arylamino)imidazoles as alpha 2-adrenergic agonists. $J$ Med Chem 1997, 40, $18-23$. 
(37) Douty, B. D.; Salvino, J. M.; Seoane, P. R.; Dolle, R. E. Synthesis of nonpeptide bradykinin B2 receptor antagonists. Bioorg Med Chem Lett 1995, 5, 363-366.

(38) Wenner, W. Bis(bromomethyl) compounds. J Org Chem 1952, 17, 523-527.

(39) Davies, W. C.; Pearse, P. L.; Jones, W. J. Tertiary phosphines containing the higher alkyl radicals. J Chem Soc 1929, 1264-1268.

(40) Stone, G. A.; Kaesz, H. D. Preparation and characterization of vinyldichlorophosphine, vinyldimethylphosphine and ethyldimethylphosphine. $J$ Org Chem 1959, 24, 635-637.

(41) Aroney, M.; Le Fèvre, R. J. W. Molecular polarisability. The conformations of various N-substituted anilines, piperidines, and piperazines. J Chem Soc 1960, 2161-2168.

(42) Morley Chem Ber 1879, 12, 1796.

(43) Poss, M. A.; Iwanowicz, E.; Reid, J. A.; Lin, J.; Gu, Z. A mild and efficient method for the preparation of guanidines. Tetrahedron Lett 1992, 33, 59335936.

(44) Brun, R.; Buhler, Y.; Sandmeier, U.; Kaminsky, R.; Bacchi, C. J.; Rattendi, D.; Lane, S.; Croft, S. L.; Snowdon, D.; Yardley, V.; Caravatti, G.; Frei, J.; Stanek, J.; Mett, H. In vitro trypanocidal activities of new S-adenosylmethionine decarboxylase inhibitors. Antimicrob Agents Chemother 1996, 40, 1442-1447.

(45) Note: the derivatised nitrogen atoms are presumably not protonated in the conditions of the assay.

(46) Denise, H.; Barrett, M. P. Uptake and mode of action of drugs used against sleeping sickness. Biochem Pharmacol 2001, 61, 1-5. 
(47) De Koning, H. P. Uptake of pentamidine in Trypanosoma brucei brucei is mediated by three distinct transporters: implications for cross-resistance with arsenicals. Mol Pharmacol 2001, 59, 586-592.

(48) Bailly, C.; Dassonneville, L.; Carrasco, C.; Lucas, D.; Kumar, A.; Boykin, D. W.; Wilson, W. D. Relationships between topoisomerase II inhibition, sequencespecificity and DNA binding mode of dicationic diphenylfuran derivatives. Anticancer Drug Des 1999, 14, 47-60.

(49) Tidwell, R. R.; Jones, S. K.; Geratz, J. D.; Ohemeng, K. A.; Cory, M.; Hall, J. E. Analogues of 1,5-bis(4-amidinophenoxy)pentane (pentamidine) in the treatment of experimental Pneumocystis carinii pneumonia. J Med Chem 1990, 33, 12521257.

(50) Cory, M.; Tidwell, R. R.; Fairley, T. A. Structure and DNA binding activity of analogues of 1,5-bis(4-amidinophenoxy)pentane (pentamidine). J Med Chem 1992, 35, 431-438.

(51) Dannert, M.; Alsasua, A.; Borrego, M. J.; Dardonville, C.; Sánchez, M.; Martin, M. I. Effects of new alpha-adrenoceptor antagonists in human prostatic tissues from patients with benign prostatic hypertrophy. Methods Find Exp Clin Pharmacol 2002, 24, Suppl. A, 158.

(52) Borrego, M. J.; Alsasua, A.; Dardonville, C.; Rozas, I.; Martin, M. I. Study of new alpha-adrenoceptor antagonists in rat blood pressure. Methods Find Exp Clin Pharmacol 2002, 24, Suppl. A, 99.

(53) Villarroya, M.; Gandia, L.; Lopez, M. G.; Garcia, A. G.; Cueto, S.; GarciaNavio, J. L.; Alvarez-Builla, J. Synthesis and pharmacology of alkanediguanidinium compounds that block the neuronal nicotinic acetylcholine receptor. Bioorg Med Chem 1996, 4, 1177-1183. 
(54) Aroney, M.; Le Fèvre, R. J. W. Molecular polarisability. The conformations of various N-substituted anilines, piperidines and piperazines. J Chem Soc 1960, 2161-2163. 
Table 1. Structure, in vitro trypanocidal activity and cytotoxicity of guanidine and 2aminoimidazoline alkane derivatives 1a-3d.

$$
\mathrm{R}_{1}-\left(\mathrm{CH}_{2}\right)_{\mathrm{n}}-\mathrm{R}_{2}
$$

\begin{tabular}{|c|c|c|c|c|c|c|}
\hline Compound & $\mathrm{n}$ & $\mathrm{R}_{1}$ & $\mathrm{R}_{2}$ & $\begin{array}{l}\text { T. brucei rhodesiense } \\
\qquad \mathrm{IC}_{50}(\mu \mathrm{M})^{\mathrm{a}}\end{array}$ & $\begin{array}{c}\text { Cytotoxicity } \\
\text { L6-cells } \\
\mathrm{IC}_{50}(\mu \mathrm{M})\end{array}$ & Selectivity \\
\hline $1 a$ & 6 & & & 8.05 & $>302$ & $>37$ \\
\hline $1 b$ & 8 & & & 0.251 & $>276$ & $>1100$ \\
\hline $1 c$ & 9 & & & 0.049 & $>265$ & $>5294$ \\
\hline $1 d$ & 12 & & & 0.047 & 0.63 & 13 \\
\hline $2 a$ & 6 & & & 19.3 & - & - \\
\hline $2 b$ & 8 & 5 & & 0.453 & 4.2 & 9.4 \\
\hline 2c & 9 & & & 0.225 & 16 & 71 \\
\hline $2 d$ & 12 & & & 0.107 & 2.35 & 22 \\
\hline $3 b$ & 8 & $\mathrm{H}$ & & 49.1 & - & - \\
\hline $3 c$ & 9 & $\mathrm{H}$ & & 19.9 & - & - \\
\hline $3 d$ & 12 & $\mathrm{H}$ & & 11.0 & 19.6 & 1.8 \\
\hline
\end{tabular}


Table 2. Structure, in vitro trypanocidal activity and cytotoxicity of guanidine and 2aminoimidazoline aza-alkane derivatives 4a-7.

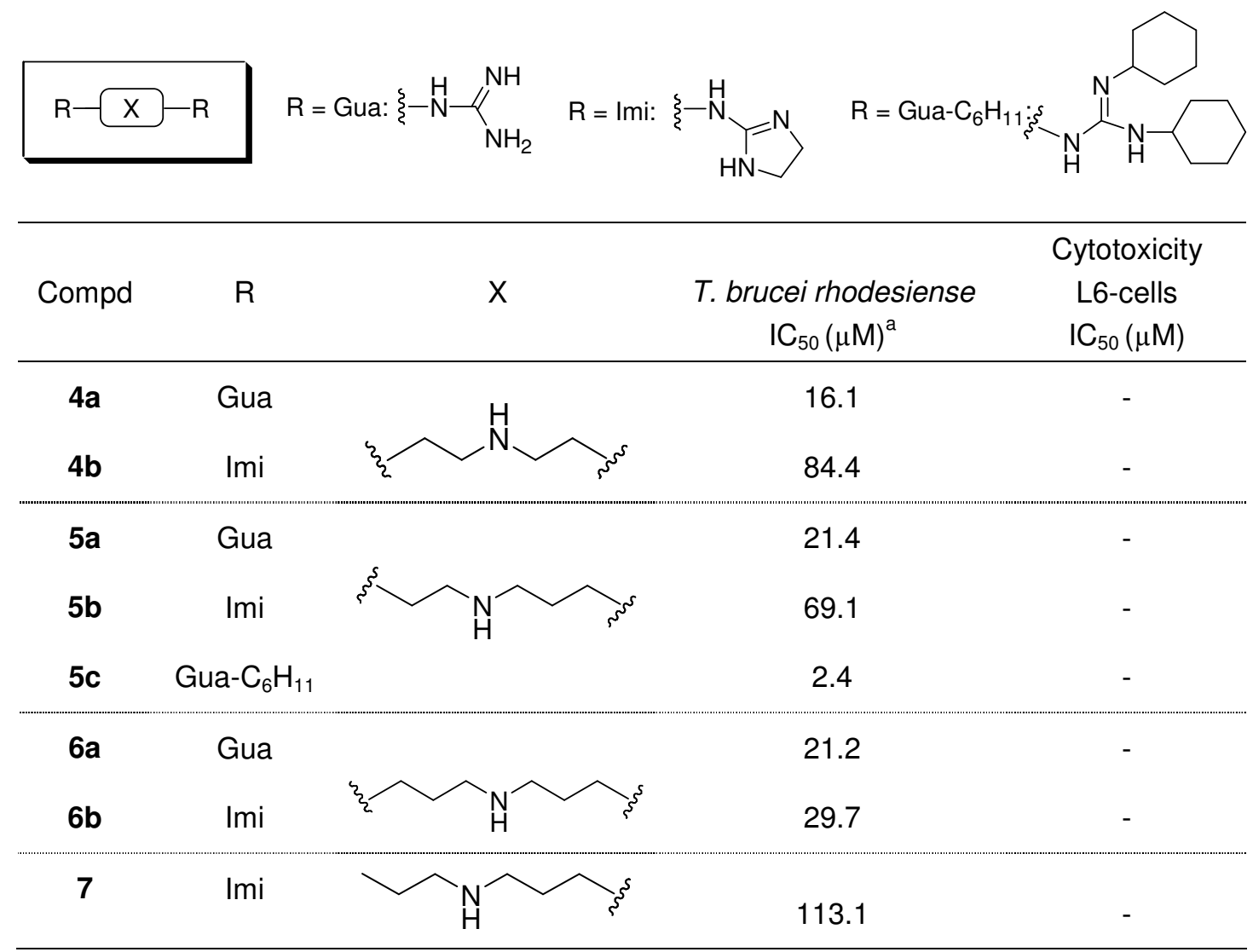

${ }^{\mathrm{a}}$ Controls: melarsoprol $\mathrm{IC}_{50}=5.5 \mathrm{nM}(\mathrm{SI}=3456)$; diminazene diaceturate $\mathrm{IC}_{50}=8.9 \mathrm{nM}$; CGP $40215 \mathrm{IC}_{50}=4.5 \mathrm{nM}$ [ref 43]. ${ }^{\mathrm{b}}$ Selectivity index (SI) expressed as the ratio [IC 50 L6-cells / $\mathrm{IC}_{50}$ T.b. rhodesiense] 
Table 3. Structure, in vitro trypanocidal activity and cytotoxicity of 3-aza-1,6hexanediamine derivatives 8-20.

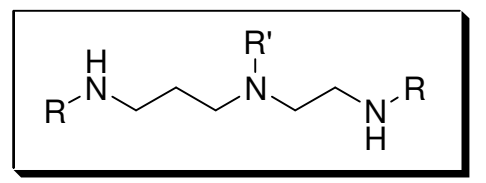

$\mathrm{R}: \mathrm{Gua}=\xi_{2}$

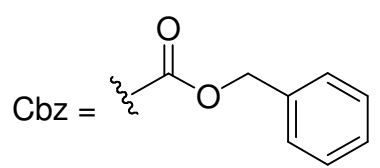

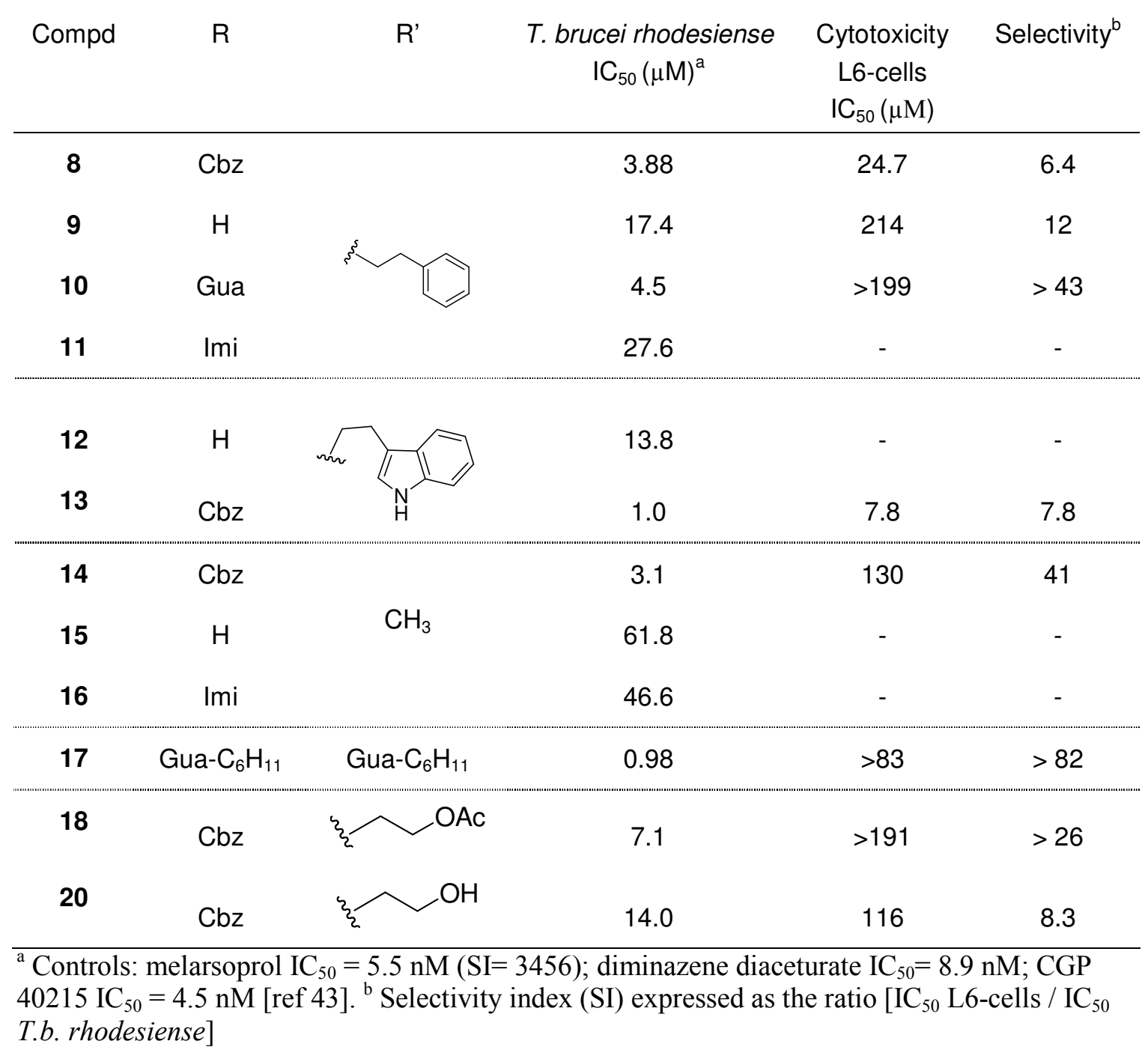


Table 4. Structure, in vitro trypanocidal activity and cytotoxicity of 3-aza-1,6-hexanediamine cyclic derivatives 21-26.<smiles>[R][R6]#[R]C=[13C]C(=O)OC(C)(C)C</smiles>

\begin{tabular}{|c|c|c|c|c|c|}
\hline Compd & Structure & $\mathrm{R}$ & $\begin{array}{l}\text { T. brucei rhodesiense } \\
\qquad \mathrm{IC}_{50}(\mu \mathrm{M})^{\mathrm{a}}\end{array}$ & $\begin{array}{c}\text { Cytotoxicity L6- } \\
\text { cells } \\
\mathrm{IC}_{50}(\mu \mathrm{M})\end{array}$ & Selectivity \\
\hline 21 & & $\mathrm{H}$ & 57.9 & - & - \\
\hline 22 & & Boc & 30.3 & - & - \\
\hline 23 & & Imi & 71.2 & - & - \\
\hline 24 & & & 12.6 & - & - \\
\hline 25 & & $\mathrm{Cbz}$ & 3.9 & 106 & 27 \\
\hline 26 & & $\mathrm{Cbz}$ & 4.78 & 89 & 18.6 \\
\hline
\end{tabular}


Table 5. Structure, in vitro trypanocidal activity and cytotoxicity of diphenyl derivatives 27a-41b.

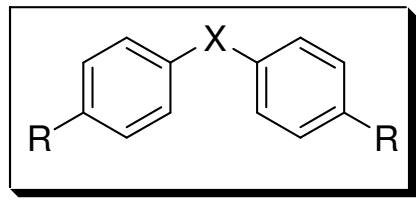

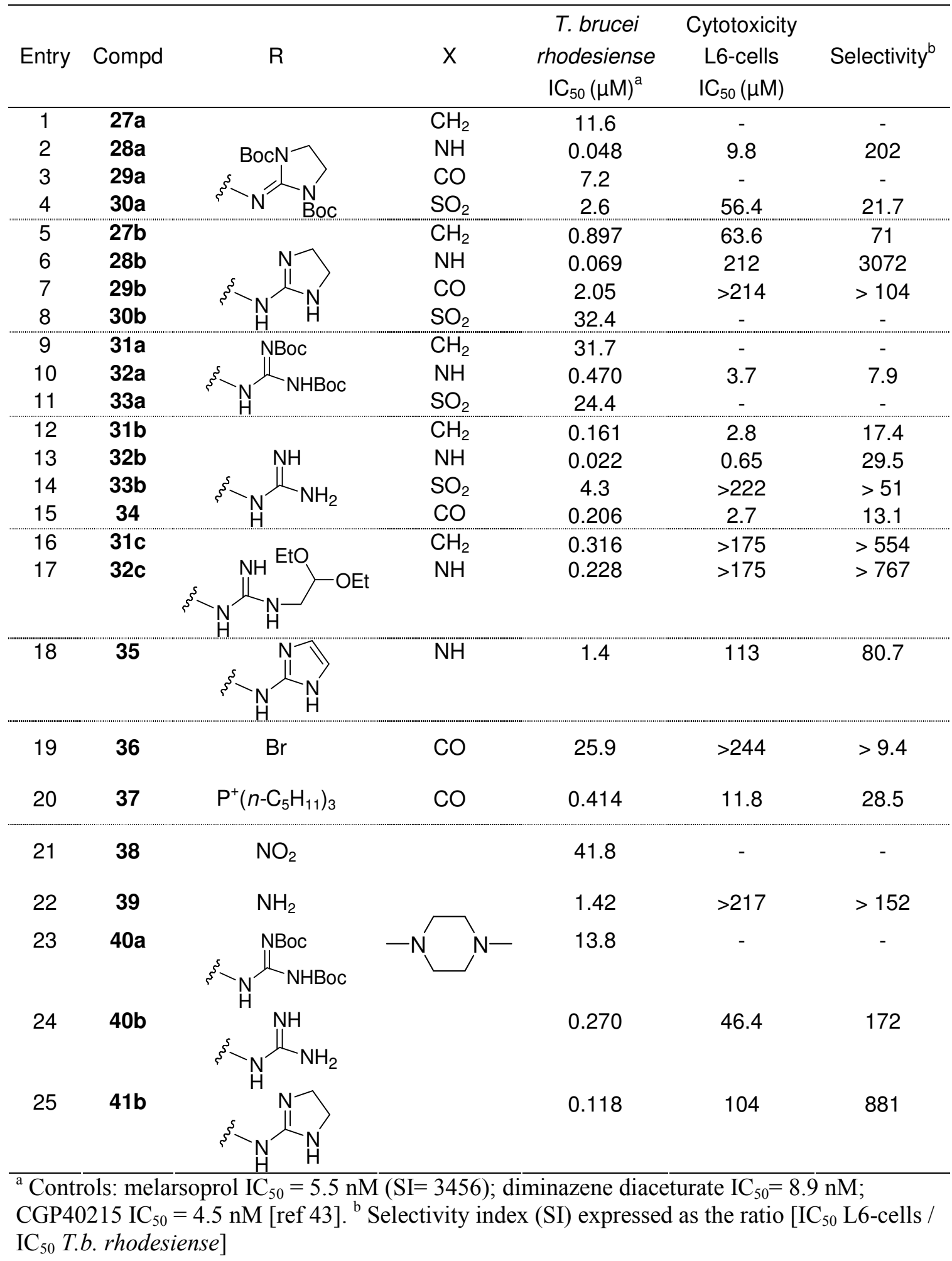

